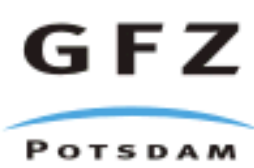

Originally published as:

Janssen, C. (2007): Different styles of faulting deformation along the Dead Sea Transform and possible consequences for the recurrence of major earthquakes. - Journal of Geodynamics, 44, 1-2, 66-89

DOI: 10.1016/j.jog.2007.01.002. 


\title{
Different styles of faulting deformation along the Dead Sea Transform and possible consequences for the recurrence of major earthquakes
}

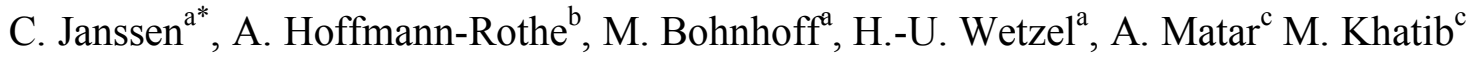 \\ and the DESERT Research Group \\ ${ }^{a}$ GeoforschungsZentrum Potsdam, Telegrafenberg, 14473 Potsdam, Germany \\ ${ }^{\mathrm{b}}$ Bundesanstalt für Geowissenschaften und Rohstoffe, Stilleweg 2, 30161 Hannover, \\ Germay \\ ${ }^{\mathrm{c}}$ Geological Department, University of Allepo, Syria
}

\begin{abstract}
We compare fault-related deformation of three segments of the major transform plate boundary between Africa and the Arabian plate, the Dead Sea Transform (DST), namely: the Arava/Araba fault (Jordan/Israel), the Serghaya fault and the Ghab fault (both Syria). These segments show both similarities and marked differences in faulting deformation and fluid-rock interactions. In the case of the Arava fault, fault damage occurs across a zone up to $300 \mathrm{~m}$ wide. A fault core/gouge zone is not exhibited. Along the Serghaya fault, the typical fault zone architecture with a main gouge zone and a damage zone of up to $100 \mathrm{~m}$ thickness is exposed. Effects of faulting in the Ghab segment are shown by subsidiary faults and the formation of fault breccias. As in the Arava fault segment, a fault core is not exposed.

Fluid-rock interactions are not equally distributed. At the Arava fault segment, the small amount of veins and the lack of alteration and dissolution processes in limestones suggest reduced fluid-rock interactions and limited fluid flow. The fault likely did not act as an important fluid conduit and hydrothermal reactions (cementation, dissolution) did not affect the strength of the fault zone. Contrary to the Arava fault, fluid-assisted fault zone healing processes (i.e. veining and cementation) were active along Serghaya fault and Ghab fault, where fault rock cementation led to
\end{abstract}

\footnotetext{
* Corresponding author. Fax: +49-331-288-1328, E-mail address: jans@gfz-potsdam.de
} 
porosity reduction and lower permeability. Such low permeability could create domains of higher pore fluid pressure, which reduce the effective shear stress required for slip on the fault. These differences in fluid-rock interactions may have played an important role with respect to the occurrence of earthquakes. We suggest that the recurrence interval on a fault segment that recovers after an earthquake without fluid assisted healing (e.g. Arava fault) should be longer than on segments with strong fluidassisted healing (cementation; e.g. Serghaya fault, Ghab fault), given that the regional stress field is the same.

Keywords: Dead Sea Transform; Faults; Paleostress field; Fault architecture; Microstructures; fault recovery

\section{Introduction}

Continental transform faults, such as the San Andreas Fault (SAF) in California, the North Anatolian Fault (NAF) in Turkey and the Dead Sea Transform (DST) are not through-going continuous fault planes. Rather they comprise structurally complex and lithologically heterogeneous zones of brittle deformation of the upper part of the crust, where segments or branches can be delimited by fault bends, stepovers or jogs (e.g., Stewart and Hancock, 1994).

However, due to the complexity of fault-related phenomena (e.g., earthquakes, stress and strain distribution, fluid flow, fault-scaling laws) studied in many publications, large fault systems are on first order considered as uniform discontinuities. Their characteristics are commonly derived along a well-studied segment or cross-profile of the fault and then extrapolated to the whole fault zone. For 
example, the multinational and interdisciplinary Dead Sea Rift Transect (DESERT 2000) that addressed some of the fundamental questions of plate tectonics (e.g., how do shear zones work and what controls them?) crosses the DST in the Central Arava Valley (Arava fault segment), where the DST appears to be structurally less complex. Using these results, the DST can be qualitatively compared to other major strike-slip faults (e.g., Ritter et al., 2003; Haberland et al., 2003; Janssen et al., 2004; DESERT 2004).

With this paper, we want to provide a closer look at similarities and differences of various fault segments of the DST itself. Previous structural studies which took place along several fault branches of the DST, such as the Arava fault (AF; e.g., Klinger et al., 2000; Diabat et al., 2004); the Serghaya fault (SF; e.g., Gomez et al., 2001; Gomez et al., 2003) and the Ghab (or Masyaf) fault (GF; e.g., Meghraoui et al., 2003; Chorowitz et al., 2005) suggest notable variations in the amount of displacement and the level of seismicity. Therefore, the question arises to what extent fault-related observations based on geophysical and geological investigations of individual fault segments are valid for large-scale strike-slip faults systems as a whole. Answering this question requires knowledge concerning fault-related deformation at different sites (segments) of one fault system.

Concentrating our study on the above mentioned three fault branches of the DST (AF, SF and GF; Fig. 1) we investigate their exhumed inventory of internal structure. The main purpose of our study is to compare (1) faulting, fault architecture, and fault kinematics at outcrop scale, (2) fluid-rock interactions and their relevance for fault weakening/healing at outcrop and microscopic scale and (3) deformation intensity and deformation conditions at microscopic scale. 


\section{Geological setting}

\subsection{Regional tectonic setting}

The Dead Sea Transform (DST) forms the plate boundary between the Arabian and African plates and accommodates their relative motion as a system of left-lateral faultbranches. It is one of the largest continental strike-slip faults in the world with more than $1000 \mathrm{~km}$ length and links the Red Sea seafloor-spreading center to the collision zone in SE Turkey. According to Butler et al. (1997) and Gomez et al. (2003) the DST can be subdivided into a southern and northern part, joined by a $\sim 200 \mathrm{~km}$ long restraining bend (Lebanese segment). The DST has been active since the middle Miocene with a total displacement of $105 \mathrm{~km}$ in the south (Bartov et al., 1980; Eyal et al. 1981; Garfunkel et al., 1981) and 70-80 km in the north (e.g. Freund et al., 1970; Dewey et al., 1986). However, the analysis of the structural displacement has been proved controversial (Westaway, 2004; Mart et al., 2005). The estimated slip rate varies between 1 and $10 \mathrm{~mm} / \mathrm{a}$ following different measurement techniques (field studies, GPS, e.g., Garfunkel et al., 1981; Klinger et al., 2000; Gomez et al., 2003; Pe'eri et al., 2002; Meghraoui et al., 2003).

The southern segment extends from the Gulf of Aquaba to the Roum fault in Lebanon (Zanchi et al., 2002). The main fault-strand of the southern DST is referred to as Arava (or Araba) fault running from the Gulf of Aqaba to the Dead Sea. The restraining band is located in Lebanon and southwestern Syria, where the fault splits into several splays including the Yammouneh and Serghaya faults. The northern segment trends N-S across Syria and splits into en echelon fault strands in southeastern Turkey (Westaway, 2004). The most prominent segment of the northern section, the Ghab (or Masyaf) fault forms the continuation of the Yammouneh fault (Fig. 1). 


\subsection{Local setting}

The NNE-SSW trending Arava fault trace is outlined by scarps, small rhombshaped grabens, pressure ridges, and displaced alluvial fan toes indicating that strikeslip faulting is still active (Galli, 1999; Klinger et al., 2000). Proterozoic igneous rocks, Mesozoic sediments and young fluviatile and aeolian sands are exposed in the area around the AF. This study was carried out at two locations (area A and B in Fig. 2a). In area $A$, the pressure ridges, where our structural analysis was mostly concentrated, exposed the exhumed part of the fault zone. The ridges consist of steeply dipping beds of limestones (Fig.3a; Kesten, 2005). Estimates of faulting conditions and the depth of faulting recorded in the exposure studied are not definitive. Janssen et al. (2004) use microstructures to argue that the uplifted Campanian-Turonian limestones were deformed at depth of 2-5 km. However, regional uplift and stratigraphic thickness indicate faulting depth of 1 to $2 \mathrm{~km}$ (Wdowinski and Zilberman, 1997; DESERT, 2004; see discussion). Study area B is located in the southern Arava Valley were the Upper Cretaceous limestones are weakly folded.

The NE-SW striking Serghaya fault is a prominent structure within the $200 \mathrm{~km}$ restraining bend of the DST located approximately along the Syrian-Lebanese border (Fig. 2b). The fault can be easily traced through the Mesozoic carbonate bedrocks (mostly Upper Cretaceous limestones) of the Anti-Lebanon Mountains to the eastern edge of the Bekaa Valley (Gomez et al., 2003). Results from paleoseismic investigations suggest an active fault with slip rates of around $1.4 \mathrm{~mm} /$ year (Fig. 3c; Gomez et al., 2001). The long-term Late-Cenozoic uplift of the Lebanese coast (0.14 $\mathrm{mm} / \mathrm{yr}$; Gomez et al., 2006) yields values of the exhumation between 2 and $2.5 \mathrm{~km}$. Local uplift along smaller structures has been even greater (Gomez et al., 2006). 
North of the Lebanon-Syria border, the DST develops from the restraining bend into the straight N-S striking Ghab fault segment (Fig. 2c). The fault crosses Upper Neogene volcanics (Homs basalt) and separates Upper Triassic and Jurassic carbonates (limestones, dolomites) from Cretaceous and Neogene to Quaternary successions (Zanchi et al., 2002). Further north left stepping of the fault allows the formation of pull-apart structures like the El Ghab basin. Palaeoseismic studies (Meghraoui at al., 2003) reveal late Holocene earthquakes with a left-lateral offset of $13.6 \mathrm{~m}$ (Fig. 3b; average slip rate $6.9 \mathrm{~mm} /$ year). Based on a geological cross section across the Syrian Coastal Range and studies of the Holocene shorelines along the Syrian coast, an uplift between $<0.1$ and $0.2 \mathrm{~mm} / \mathrm{yr}$ could be established (Sanlaville et al., 1997; Gomez et al. 2006). Using these data, we assume a range of exhumation for the Ghab fault segment between 1.5 and $3 \mathrm{~km}$.

\section{Fault architecture and fault zone character}

Following a conceptual model of fault zone architecture, a brittle fault zone can be divided into three distinct components defined by relative deformation intensity (e.g. Chester and Logan, 1986; Caine et al., 1996): (1) The narrow fault core, which is composed of clay-gouges, cataclasites or chemically altered rocks. Most of the displacement is localized within the fault core; (2) the damage zone, which comprises highly, fractured rocks bounding the fault core on both sides; (3) the unfaulted host rock or protolith, which surrounded fault core and damage zone. The distribution of fault rocks has significant impact on the mechanical and hydrologic behaviour of faults (Evans and Chester, 1995; Schulz and Evans, 1998, 2000). Therefore, characterization of the internal structure of exhumed fault zones is important for understanding their mechanical, hydraulic and seismic behaviour (Conti et al., 2001; 
Faulkner et al., 2003; Wibberley and Shimamoto, 2003). In particular, the analysis of deformation mechanisms and healing processes (cementation and compaction) provide information about temporal and spatial changes in the strength of faults (Sleep and Blanpied, 1992; Schulz and Evans, 1998; Janssen et al., 1998; Muchez and Sintubin, 1998; Lin et al, 2001; Sausse et al., 2001).

The Arava fault is represented by fault breccias (limestones with more than $30 \%$ of visible fragments; Sibson 1977) and fractured rocks, which are developed on either side of the fault. However, clay gouges and cataclasites were not observed. Faultrelated veins are rare and fault breccias are not cemented suggesting that fluid-assisted healing processes are negligible (Fig. 3e). In the southern Arava Valley (study area B), brittle fault damage forms a zone up to $300 \mathrm{~m}$ wide (Janssen et al. 2004). Highresolution seismic investigations characterize the shallow part of the $\mathrm{AF}$ as a rather broad (100 - $300 \mathrm{~m}$ wide) heterogeneous zone of deformed and displaced material (Haberland et al, 2007).

The Serghaya fault exhibits a change in style of fault rocks approaching the fault trace in some exposures (Fig. 4). Figure 4a shows the distribution of damage elements (subsidiary faults, fractures, veins) perpendicular to the fault. Following the profile from southwest to northeast, a slight increase of damage elements toward the fault core is evident. In the alteration zone the number of damage elements decreases followed by a renewed increases further to northeast. This reflects typical fault zone architecture composed of protolith rocks, damage zone and fault core at macroscopic scale (Fig. 4b). The fault core consists of $\mathrm{a} \sim 5$ to $10 \mathrm{~m}$ wide fluid alteration zone with intense material comminution (Fig. 3f). Inside the alteration zone, fine-grained green and black slices of a clay gouge (100 to $200 \mathrm{~mm}$ thick) can be identified. The clay gouge is poorly foliated (Fig. 3d). The damage zone consists of heterogeneously deformed and heavily brecciated limestones and fractured rocks. Both, fault breccias 
and fractured rocks are mostly cemented by calcite indicating that fluid-assisted healing processes were active (Fig. 3g). The decreasing abundances of veins and cemented breccias away from the fault suggest that the fault served as channel for calcite-bearing fluids. The intensity of fracturing drops off markedly at approximately $50 \mathrm{~m}$ from the main fault trace and the orientation of fractures scatter more than those in the damage zone. The protolith (host) rocks are only weakly fractured.

The Ghab fault contains normal faults, thrusts, subsidiary faults and associated intense macro-fracturing (Fig. 3h; see also Zanchi et al. 2002). Jurassic and Cretaceous carbonates (dolomite, limestone) reveal a progressive fault rock variation with proximity the fault trace. Adjacent to the major fault trace, fault-related deformation has resulted in the formation of fault breccias. However, contrary to the SF and in spite of many fault-related exposures there is no outcrop providing a complete picture of the fault architecture. A distinct fault core is not exposed. Solely within the damage zone, individual bands of small fault gouges are discernable. Fracture healing by cementation is more intense than in the AF area but to a lesser extent than the SF.

\section{Fault Kinematics}

The DST has been the subject to numerous detailed kinematic studies, mostly derived from regional structures (e.g. Eyal et al., 1981; Eyal and Reches, 1983; Eyal, 1996; Eyal at al., 2001). Kinematic analyses on outcrop scale are less frequent and are mostly located along the AF and GF segments (Matar and Mascle, 1993; Zanchi et al., 2002; Diabat et al., 2004; Janssen et al., 2004; Chorowicz et al., 2005). The following reviews new and published kinematic data. 


\subsection{Methods}

The survey presented here comprises more than 45 sites, mostly located in outcrops of Upper Triassic, Jurassic and Cretaceous carbonates adjacent to the main fault trace. However, a sufficient number of fault-slip data was found at 16 sites only. Crosscutting relationships, for example superposed striations on single fault planes, have been used to establish the relative faulting chronology.

Local incremental strain tensors with shortening and extension axes were derived using the kinematic approach of Allmendinger (2001, program FaultKin 4.0; see also Maret and Allmendinger, 1990). The results of kinematic analysis are presented as fault plane solutions. To determine the stress field orientation we applied a stress tensor inversion. This technique allows determining the orientation of the three principal stress axes $\left(\sigma_{1}=\right.$ maximum, $\sigma_{2}=$ intermediate and $\sigma_{3}=$ minimum $)$ as well as a relative stress magnitude $\mathrm{R}=\left(\sigma_{1}-\sigma_{2}\right) /\left(\sigma_{1}-\sigma_{3}\right), 0<\mathrm{R}<1$. A detailed description of this method and its application to varying data sets is given by Gephart and Forsyth (1984), Michael (1991), Hardebeck and Hauksson (2001) and Bohnhoff et al. (2004).

\subsection{Results}

Along the Arava fault three main fault sets, with some scattering in orientation, could been distinguished (Fig. 5a): NW-SE trending dextral faults are more abundant than E-W trending dextral and N-S trending sinistral faults (left). P- and T-axes are sub-horizontal (middle). The composite fault plane solution in Figure 5a (right) reveals a strike-slip fault regime with sub-horizontal NW-SE (WNW-ESE) shortening and NE-SW extension for all locations. Results of stress tensor inversion, comprising a total of 53 fault sets, reveals a subhorizontal NW-trending direction of $\sigma_{1}$ and an almost vertical orientation for $\sigma_{2}$ reflecting a strike-slip regime (Fig. 5d). The relative 
stress magnitude is $\mathrm{R}=0.43$ indicating that the magnitude of $\sigma_{2}$ is approximately half way between $\sigma_{1}$ and $\sigma_{3}$.

For the Serghaya fault, at least two faulting events could be established. At sites SF4-1, the older faulting event is composed of two main fault sets. E-W trending sinistral faults are more abundant than N-S (NE-SW) trending dextral faults (Fig. 5b, left). The distribution of $\mathrm{P}$ and $\mathrm{T}$ axes indicate dominantly left-lateral strike slip with some scattering in orientation (Fig. 5b, middle). The fault plane solution in Fig. $5 b$ (right) shows strike-slip faulting with a NW-SE shortening axis. The younger set (SF4-2) contains NE-SW (NNE-SSW) and E-W trending faults. The shortening direction rotates clockwise to an approximate NNW-SSE orientation. At site SF9, only NW-SE striking normal faults were identified. Superposed striations along the same fault plane indicate that high-angle sinistral faults (SF9-1, older event, Fig. 5b) have been reactivated as normal faults (SF9-2, younger events, Fig. 5b). The composite fault plane solution for the older event indicates subhorizontal NW-SE shortening and NE-SW extension. For the younger event, fault plane solution suggests NNE-SSWextensional normal faulting and strongly preferred orientation of $\mathrm{P}$ and $\mathrm{T}$ axes in a dense cluster of events (Fig 5b). The stress tensor inversion results for the Serghaya fault also reflect the two dominant faulting regimes identified in this area by the high value of the relative stress magnitude (0.71), i.e., $\sigma_{1}$ and $\sigma_{2}$ do not differ significantly in their magnitude and have a similar trend of $\sim \mathrm{N} 145^{\circ} \mathrm{E}$. This is also documented by their overlapping confidence intervals (Fig. 5d). $\sigma_{3}$ is clearly separated and thus well constrained at a subhorizontal NE-SW trend. The results confirm that NE-SW extensional and strike-slip faulting dominates the Serghaya fault segment.

Within the area of the Ghab fault, fault orientation and kinematic axes scatter more than those along the Serghaya fault. Along the southern segment between the Al Ghab basin and the Lebanese border (GF14, GF15, GF29, GF39) NE-SW (ENE-WSW) 
trending strike-slip faults (dominant) are associated with NW-SE (WNW-ESE) striking faults (Fig. 5c). Kinematic reconstruction mainly suggests NW-SE shortening and NE-SW extension (GF29), E-W shortening and N-S extension (GF15, GF39) and NE-SW shortening and NW-SE extension (GF14). Along the western und eastern Flank of the Al Ghab basin fault sets with N-S (NNE-SSW), NW-SE and WNW-ESE trending faults are dominant (GF16, GF23 and GF27; Fig 5c). The $\mathrm{P}$ and $\mathrm{T}$ axes derived again indicate NW-SE shortening and NE-SW extension. The stress tensor inversion result for the whole Ghab segment reveals a well-resolved strike-slip regime with a sub-horizontal NW-SE $\sigma_{1}$-direction (Fig. 5d). Thus, it is similar to the stress field orientation obtained for the Arava fault.

In summary, our fault-slip data indicate a similar paleostress configuration for the fault segments selected. We observed no major changes between the principal orientations of the regional stress field along the selected fault segments during the time period covered by our data (Fig. 5d). The summarized inversion results for the three fault branches indicate a NW-SE orientation of $\sigma_{1}$ in an almost pure strike-slip regime ( $\mathrm{AF}, \mathrm{GF})$ and a strike-slip regime with an extensional component $(\mathrm{SF})$. At local scale, the derived shortening directions vary between NNW-SSE and WNW-ESE and the extension between ENE-WSW and NNE-SSW (with exception of GF14). These observations are compatible with previous published regional stress data. Eyal (1996), Eyal et al. (2001) and Diabat et al. (2004) postulated two main stress regimes for the western and eastern margin of the DST. The first with WNW shortening and NNE extension, starting in the Turonian, is probably associated with the Syrian Arc fold belt (Syrian Arc stress field/SAS). The second paleostress field from middle Miocene to recent is characterized by NNW-SSE shortening and ENE-WSW extension. This stress field is associated with the $105-\mathrm{km}$ sinistral displacement along the DST and the opening of the Red Sea (Dead Sea stress Field/DSS). Further, Eyal 
(1996) concluded that the SAS stress field continued up to recent and that DSS movements are superimposed upon them. Zanchi et al. (2002) postulated that a NWSE compression direction is related to the Syria Segment of the DST.

\section{Microscopic observations}

Microscopic observations have been predominantly performed on fault rock samples with calcite/dolomite veins because vein crystals have the required size to characterize the different types of cement and to detect microstructures. Veins are fault-related as suggested by their abundances, which progressively increase toward the main fault trace, and by their low angles orientation with respect to the fault.

\subsection{Methods}

Cathodoluminescence (CL): CL microscopy was used to identify different cement zonations. Variations in the cathodoluminescent properties of carbonates are usually attributed to a different trace element composition of the original fluids from which the calcite precipitated. Fault-related microstructural features in vein calcites were used to estimate (a) deformation intensity, (b) deformation temperatures and (c) paleodifferential stress magnitudes (paleopiezometer).

Deformation intensity: To estimate fault-related deformation intensity at microscale, a point-count method was used to determine quantitatively the relative abundance of different microstructures (see $\mathrm{Wu}, 1993$ ). Counting of 500 points was performed along five 20-mm-long traverses for each thin section. Points were tabulated within five categories (undeformed matrix, microfractures, twins, pressure solution and undeformed cement). 
Deformation temperatures: Deformation temperatures were estimated from calcite twins. We use the fact that twin width and twin type correlate directly with temperatures of deformation (e.g. Ferrill, 19991; Burkhard, 1993; Ferrill et al., 2004). Thin twins $(<1 \mu \mathrm{m})$ dominate below $170^{\circ} \mathrm{C}$ and thick twins dominate above $200^{\circ} \mathrm{C}$, whereas above $250^{\circ} \mathrm{C}$ dynamic recrystallization becomes more important (Ferrill et al., 2004). Widths of thin and thick twins were measured separately using a U-Stage.

Paleodifferential stress magnitudes (paleopiezometer): Two approaches based on calcite twins are used to estimate differential stress magnitudes $(\Delta \sigma)$. The method from Jamison and Spang (1976) is based on theoretical considerations of glide and twin systems in calcite and dolomite. The technique is best applied in coarse-grained carbonates, where strain is small and deformation temperatures below $200^{\circ} \mathrm{C}$ (Burkhard, 1993; Ferrill, 1998). A second approach to differential stress estimation is based on twin density (Rowe and Rutter, 1990). The twin-density technique is preferred for samples deformed at higher strain and higher temperatures $\left(>200^{\circ} \mathrm{C}\right.$; Ferrill, 1998). For the purpose of our work we firstly estimated the temperature range and then we decided which of both approaches we used.

\subsection{Results}

\subsubsection{Cathodoluminescence characteristics}

The vein cement of the AF segment shows the whole spectrum of CLcharacteristics. In area A, at least two vein cement generations could be detected. An older cement from samples adjacent to the main fault trace (pressure ridges) reveals growth zones with orange to dark orange CL-colours (Fig. 6a,b), whereas the luminescence colours of some younger veins vary from dark to nonluminescent (Janssen et al. 2005). The calcite veins from samples of area B have bright CL-colours similar to those of surrounding host rock. The different CL-colours may suggest 
repeated infiltration of fluids with different trace element compositions while the similarity of luminescence suggests that vein calcites was locally derived from the host rock.

The CL-microscopic observations of faulted rocks from the SF segment show considerable differences in CL-colors between selected fault rocks. In fault breccia samples the fault matrix luminesces brightly orange whereas the subangular carbonate fragments luminesce dark red (Fig. 6c,d). In the group of deformed veins, the twinned and fractured calcite cement luminesces in the same orange color as the sedimentary host rock. In contrast, younger (undeformed) veins and their surrounding host rock luminesce intrinsic blue or do not luminesce (Fig. 6e,f). These calcites contain no trace elements that would provide a bright CL-signature.

Fault rocks from the Ghab fault show different CL-colors for matrix and calcite cementation. At least two distinct episodes of calcite cementation are distinguishable. The sedimentary matrix has purple CL-colors, whereas older vein cement luminesces orange and the younger one luminesces deep blue (Fig. 6g,h). Vein dolomite shows growth zones with different CL-colors. The interior zone luminesces red (dark red) whereas the outer zone luminesces orange (Fig. 6i, j).

In summary, fault rocks of all selected fault branches exhibit up to three phases of calcite cementation. The different CL-patterns are best interpreted in terms of changing redox conditions (Meyers, 1978). The older brightly luminescent cement could be precipitated under meteoric phreatic to deep burial conditions, while the younger blue or non-luminescent cement is thought to have precipitated under near surface oxidizing conditions (Verhaert et al., 2004). 


\subsubsection{Microstructural analysis}

The distribution of microstructures and the derived deformation temperatures and differential stress data shown in Fig. 7a-c are a combination of previously published data (AF; Janssen et al. 2004) and new data (SF and GF).

AF samples collected from pressure ridges in area A (A2, A4, A5, A8), adjacent to the main fault trace, have a higher percentage of microstructures $(\sim 35 \%$ to $\sim 55 \%)$ than samples at a distance more than $150 \mathrm{~m}$ from the fault $(<15 \%$; A6, A10; Fig. 7a). Deformation temperatures derived from the appearance of twins (Burkhard, 1993) vary between $150^{\circ} \mathrm{C}$ and $300^{\circ} \mathrm{C}$ and the maximum differential stress derived from microstructures differs between 100 and $200 \mathrm{MPa}$. In area B, veins are fractured but only a small part of vein calcite is twinned (Fig. 7a). The straight and thin twin lamellae $(<1 \mu \mathrm{m})$ suggest deformation at low temperatures $\left(<170^{\circ} \mathrm{C}\right)$ and small differential stress magnitudes (20-35 MPa; Janssen et al. 2004).

Thin section of cemented fault breccias from the SF segment reveal unequal deformed vein arrays. Deformation intensity in older veins is comparable with the deformation along the AF. As described for the AF, the deformation intensity differs markedly between the selected locations. In samples collected adjacent to the fault trace (site SF4: S5, S6, S7), the results of point counting display higher percentages of fracturing and twinning than average (Figs. $4 \mathrm{c}$ and $7 \mathrm{~b}$ ). Twin sets with bent and thick lamellae (>1 $\mu \mathrm{m}$; Ferrill, 1991; Ferill et al. 2004) are more frequent than thin twins. Both, the appearance of twin sets (classified as type II and type III twins after Burkhard, 1993) and the thickness of twin lamellas indicate a range of deformation temperatures between $<170^{\circ}$ and $250^{\circ} \mathrm{C}$. Applying twinning paleopiezometry (Rowe and Rutter method) we estimated differential stress magnitudes between 30 and 200 $\mathrm{MPa}$. Near the main fault trace the fractures were healed by younger calcites (latest 
vein generation) with elongated to fibrous habit suggesting slow opening by aseismic slip (Gratier and Gamomd, 1990). These crystals are not twinned and fractured indicating that healing processes (cementation) outlasted brittle faulting.

Microscopic observations of fault breccias from the Ghab fault show different microstructures in calcite and dolomite cement. In contrast to fracturing which are observed in all thin sections, twinning is confined to calcite cement (Fig. 7c). Related to the whole GF, twinning in calcite is less common than in the area of AF and SF (Fig. 7a-b). With exception of sample G24, only twin sets with straight and thin twin lamellae $(<1 \mu \mathrm{m})$ have been observed. By their appearance, they are classified as type I twins (Ferril, 1991; Burkhard, 1993), suggesting deformation at low temperatures $\left(<170^{\circ} \mathrm{C}\right)$. The derived paleo-differential stress (using the Jamison and Spang method) varies between 20 and $33 \mathrm{MPa}$. Only in sample G24 (location GF25) microstructures reveal a substantial internal deformation (206 MPa, 200-250 ${ }^{\circ} \mathrm{C}$; Fig. 7c). As described for the SF, the younger vein calcites with elongated to fibrous habits are not twinned.

Comparison between all selected exposures shows that brittle fracturing and twinning are the dominant deformation mechanisms in the three DST segments we studied (Fig. 7a-c). Both deformation mechanisms become more intense toward the fault trace. However, the percentage of twinned grains in AF and SF are markedly higher than in the GF segment. Some of the SF and GF vein cements are complete undeformed suggesting that fault healing outlasted brittle failure (Fig. 8). Dolomite veins within the GF segment comprise coarse, clear white dolomites that tend to be zoned under the CL-microscope and bladed sometimes clear, scalenohedral cements (Fig. 6j). Both cement types are fractured. Moreover, the amount and appearance of deformation mechanisms in calcite and dolomite in conjunction with cement types, CL observations and crosscutting relations indicate at least four different stages of cementation (Table 1). 


\section{Discussions and Conclusion}

The above presented fault data and observations are summarized and compared in Table 1 and 2. The deformation conditions for the three segments appear to be similar, according to samples analysed from the exhumed fault. However the deduced temperature is a "key weakness" of our results, because the estimated temperature range for the oldest vein generation $\left(250^{\circ}-300^{\circ} \mathrm{C}\right)$ is not consistent with the assumed depth of faulting $(1-3 \mathrm{~km})$ judged by the stratigraphic thickness and regional uplift. Even though local uplift rates are greater (Gomez et al. 2006), the temperature has not exceeded $150^{\circ} \mathrm{C}$ assuming an average geothermal gradient. Therefore temperature values derived from microstructures are probably overestimated. We assume that twin morphology is not only a function of deformation temperatures but also depends on differential stress and strain rate.

The kinematic analysis of the three studied segments reflects paleostress orientations that are in accordance to the present-day orientation of the sinistral strikeslip DST. Except for some deflections, where the DST follows the restraining bend, neither major spatial nor chronological variations in the orientation of the paleostress tensors are evident, showing that the regional (large-scale) kinematic system of the DST can indeed be extrapolated to its entire length. However, where fault architecture and fluid-rock interaction is concerned the three fault segments reveal some remarkable differences. The complete fault zone architecture is exposed only along the SF. Fluid-rock interaction seems to be negligible along the AF. Along the SF- and GFsegments in contrast, fluid-rock interaction is of great importance as evidenced by the abundance of veins and fracture cementation. Where fluid-rock interaction is intense, fault zone architecture resembles the classical model described in the introduction. 
Therefore the DST cannot be generalized along its entire length regarding fault architecture and fluid involvement. These differences along strike may have some importance for the earthquake potential of the studied segments. Recent models of fault evolution propose a cyclic nature of earthquake faulting processes where faults act as seals during seismic quiescence and as conduit during earthquakes (e.g. Sibson, 1992; Rice, 1992; Sleep and Blanpied, 1992; Caine et al., 1996; Miller et al., 1996; Miller, 2002). The basic assumption is that pore pressure increases within the fault zone during tectonic loading and decreases during faulting. This process requires the repeated creation and destruction of permeability within the fault zone due to fracturing and cementation, respectively. Relating this model to our results, we suggest that the investigated segments were deformed under different conditions during the inter-seismic period of cyclic fault evolution (Fig. 9).

At the SF and GF segments, the presence of fluids facilitated an extensive fault rock cementation. We assume that healing led to partial or complete recovery of the SF and GF. The healing of fractures by mineral precipitation leads to porosity reduction and lower permeability. Such low permeability could create domains of higher pore fluid pressure, which reduce the effective shear stress required for the slip on the fault (Fig. 9a; Faulkner and Rutter, 2001; Miller 2002). Our observation is supported by experiments (Muhuri et al., 2003) and inspections from fault rocks of the Nojima fault, where in less than three years the chemical processes cemented the earthquake-induced fractures and strengthened the fault zone to allow new fracturing (Moore et al. 2000). Muhuri et al. (2003) hypothesize that crustal fault zones could be lithified during the interseismic period and the extent of this lithification would control earthquake-slip instability.

The investigation of the exhumed part of the AF segment suggests that fluidassisted cementation of fault material played only a minor role in the fault evolution 
(Fig. 9b). This is supported by results of conductivity studies across the AF, which suggest that the fault does presently not act as a fluid conduit (Ritter at al., 2003). One may reason that the earthquake recurrence interval on a fault segment that recovers after an earthquake without fluid assisted healing (e.g. AF) should be longer than on segments with strong fluid-assisted healing (cementation; e.g. SF, GF), given that the regional stress field is the same. This assumption is consistent with studies of historical earthquakes and palaeoseismic investigations (Table 2; Ben-Menahem, 1991; Klinger et al, 2000, Gomez et al. 2003, Begin et al., 2005, Kagan et al., 2005). The region along the AF segment has been the least seismically active region during the past 3000 years, whereas the northern segments were the most seismically active zones along the DST (Ben-Menahem, 1991).

\section{Acknowledgements}

This work is part of the collaborative research program DESERT funded by the German Science Foundation (DFG), the GeoForschungsZentrum (GFZ). The authors wish to thank to M. Weber for many helpful discussion and A. Hendrich for help with drafting. Helpful comments by D. Faulkner improved the quality of this manuscript. We also thank J. Götze for assistance in obtaining high-quality CL-photographs. A constructive review by K. Benn and an anonymous referee are acknowledged.

\section{References}

Allmendinger, R.W., 2001. FaultKin 4.0 X. Computer Program with documentation, Cornell University, Ithaca, NY, USA.

Amit, R., Zilberman, E., Enzel, Y., Porat, N., 2002. Paleoseismic evidence for time dependency of seismic response on a fault system in the southern Arava Valley, Dead Sea rift, Israel. Geol. Soc. Am. Bull. 114, 192-206. 
Bartof, Y., Steinitz, G., Eyal, M., Eyal, Y., 1980. Sinistral movement along the Gulf of Aquaba - its age and relation to the opening of the Red Sea. Nature 285, 220-222.

Begin, Z.B., Steinberg, D.M., Ichinose, G.A., Marco, S., 2005. A 40,000 year unchanging seismic regime in the Dead Sea rift. Geology 33, 257-260.

Ben-Menahem, A., 1991. Four thousend years of seismicity along the Dead Sea Rift. J. Gephys. Res. 96, 20195-20216.

Bonhoff, M., Baisch, S., Harjes, P., 2004. Fault mechanisms of induced seismicity at the super deep German continental Deep Driling Program (KTB) borehole and their relation to fault structure and stress field. J. Geophys. Res. 109(B02309), doi:10.1029/2003JB002528.

Butler, R.W. H., Spencer, S., Grifiths, H.M., 1997. Transcurrent fault activity on the Dead Sea Transform in Lebanon and its implication for plate tectonics and seismic hazard. J. Geol. Soc. Lond. 154, 757-760.

Burkhard, M., 1993. Calcite-twins, their geometry, appearance and significance as stress-strain markers and indicators of tectonic regime: a review. J. Struct. Geol. 15, $351-368$

Caine, J.S., Evans, J.P., Forster, C.B., 1996. Fault zone architecture and permeability structure. Geology 24, 1025-1028.

Chester, F.M., Logan, J.M., 1986. Impication for mechanical properties of brittle faults from observations of Punchbowl fault zone, California. Pure Apll. Geophys. $124,79-106$.

Chorowitz, J., Dhont, D., Ammar, O., Rukieh, M., Bilal, A., 2005. Tectonics of the Pliocene Homs basals (Syria) and implications for the Dead Sea Fault Zone activity. J. Geol. Soc. Lond. 162, 259-271. 
Conti, A., Turpin, L., Plino, R., Mattei, M., Zuppi, G.M., 2001. The relationship between evolution of fluid chemistry and the style of brittle deformation: examples from the Northern Apennines. Tectonophysics 330, 103-117.

DESERT Team, 2000. Multinational Geoscientific Research Effort Kicks off in the middle East. EOS, Transactions 81, pages 609, 616-617.

DESERT Team, 2004. The crustal structure of the Dead Sea Transform. Geophys. J. Int. 156, 655-681.

Dewey, J.F., Hempton, M.R., Kidd, W.S.F., Saroglu, F., Sengör, A.M.C., 1986. Shortening of continental lithosphere: the neotectonics of Eastern Anatolia - a young collision zone. In: Coward, M.P., Ries, A.C. (Eds.), Collision Tectonics, Spec. Publ.-Geol. Soc. Lond. 19, pp. 3-36.

Diabat, A.A., Atallah, M., Salih, M.R., 2004. Paleostress analysis of the Cretaceous rocks in the eastern margin of the Dead Sea Transform, Jordan. J. Afr. Earth Sci. 38, $449-460$

Evans, J.P., Chester, F.M., 1995. Fluid-rock interaction in faults of the San Andreas system: Inferences from San Gabrial fault rock geochemistry and microstructures. J. Geophys. Res. 100, 13,007-13,020.

Eyal, Y., Reches, Z., 1983. Tectonic analysis of the Dead Sea rift region since the Late-Cretaceous based on mesostructures. Tectonics 2, 167-185.

Eyal, M., Eyal, Y., Bartov, Y., Steinitz, G., 1981. The tectonic development of the western margin of the Gulf of Elat (Aquaba) Rift. Tectonophysics 80, 39-66.

Eyal, Y., 1996. Stress field fluctuations along the Dead Sea rift since the middle Miocene. Tectonics 15, 157-170.

Eyal, Y., Gross, M.R., Engelder, T., Becker, A., 2001. Joint development during fluctuation of regional stress field in southern Israel. J. Struct. Geol. 23, 279-296. 
Faulkner, D.R., Rutter, E.H., 2001. Can the maintenance of overpressured fluids in large strike-slip fault zones explain their apparent weakness? Geology 29, 503-506.

Faulkner, D.R., Lewis, A.C., Rutter, E.H., 2003. On the internal structure and mechanics of large strike-slip fault zones: field obersations of the Carboneras fault in southern Spain. Tectonophysics 2003, 235-252.

Ferrill, D.A., 1991. Calcite twin widths and intensities as vmetamorphic indicators in natural low-temperature deformation in limestones. J. Struct. Geol. 13, 667-675.

Ferrill, D.A., 1998. Critical re-evaluation of differential stress estimates from calcite twins in coarse-grained limestone. Tectonophysics $285,77-86$.

Ferrill, D.A., Morris, A.P., Evans, M.A., Burkhard, M.; Groshong, R.H., Onasch, C.M., 2004. Calcite twin morphology: a low-temperature deformation geothermometer. J. Struct. Geol. 26, 1521-1529.

Freund, R., Garfunkel, Z., Zak, I., Goldberg, M., Derin, B., Weissbrod, T., 1970. The shear along the Dead Sea rift. R. Soc. London Phil. Trans. A 267, 107-130.

Galli, P., 1999. Active tectonics along the Wadi Arava-Jordan Valley. J. Geophys. Res. 104, 2777-2796.

Garfunkel, Z., Zak, I., Freund, R., 1981. Active faulting in the Dead Sea rift. Tectonophysics 80, 1-26.

Gephart, J.W., Forsyth, D.W., 1984. An improved Method for Determining the Regional Stress Tensor Using Earthquake Focal Mechanism Data: Application to the San Fernando Earthquake Sequence. J. Geophys. Res. 89, 9305-9320.

Gomez, F., Meghraoui, M., Darkal, A.N., Sbeinati, R., Darawcheh, R., Tabet, C., Khawlie, M., Barazangi, M., 2001. Coseismic displacements along Serghaya Fault: An active branch of the Dead Sea Fault System in Syria and Lebanon. J. Geol. Soc. Lond. 158, 405-408. 
Gomez, F., Meghraoui, M., Darkal, A.N., Hijazi, F., Mouty, M., Suleiman, Y., Sbeinati, R., Darawcheh, Al-ghazzi, R., Barazangi, M., 2003. Holocene faulting and earthquake recurrence along the Serghaya branch of the Dead Sea fault system in Syria and Lebanon. Geophys. J. Int. 153, 658-674.

Gomez, F., Khawlie, M., Tabet, C., Darkal, A.N., Khair, K., Baranzangi, M., 2006. Late Cenozoic uplift along the northern Dead Sea transform in Lebanon and Syria. Earth Planet. Sci. Lett. 241, 913-931.

Gratier, J.P., Gamond, J.F., 1990. Transition between seismic and aseismic deformation in the upper crust. In: Knipe, R.J., Rutter E.H. (Eds.), deformation mechanisms, rheology and tectonics, Geol. Soc. Lond. Spec. Publ. 54, 461-473.

Haberland, C., Agnon, A., El-Kelani, R., Maercklin, N., Qabbani, I., Rümpker, G., Ryberg, T., Scherbaum, F., Weber, M., 2003. Modelling of seismic guided waves at the Dead Sea transform. J. Geophys. Res. 108, doi: 10.1029/2002JB002309.

Haberland, C., Maercklin, N., Kesten, D., Ryberg, T., Janssen, C., Agnon, A., Weber, M., Schulze, A., Qabbani, I., El-Kelani, R., 2007. Shallow fault anatomy of the Wadi Arava fault (Dead Sea Transform) from high-resolution seismic investigations. Tectonophysics (in press)

Hardebeck, J.L., Hauksson, E., 2001. Stress Orientations Obtained from Earthquake Focal Mechanisms: What are Appropriate Uncertainty Estimates?, Bull. Seismol. Soc. Am. 91, 250-262.

Jamison, W.R., Spang, J.H., 1976. Use of calcite twin lamellae to infer differential stress. Geol. Soc. Am. Bull. 87, 868-872.

Janssen, C., Laube, N., Bau, M., Gray, D.R., 1998. Fluid regime in faulting deformation of the Waratah Fault Zone, Australia, as inferred from major and minor element analyses and stable isotopic signatures. Tectonophysics 294, 109-130. 
Janssen, C., Romer, R.L., Hoffmann-Rothe, A., Kesten, D., Al-Zubi, H., 2004. The Dead Sea Transform: Evidence for a strong fault? J. Geol. 112, 561-575.

Janssen, C., Romer, R.L., Hoffmann-Rothe, A., Mingram, B., Dulski, P., Möller, P., Al-Zubi, DESERT Research Group, 2005. The role of fluids in faulting deformation: a case study from the Dead Sea Transform. Int. J. Earth. Sci. 94, 243255.

Kagan, E.J., Agnon, A., Bar-Matthews, M., Ayalon, A., 2005. Dating large infrequent earthquakes by damaged cave deposits. Geology 33, 261-264.

Kesten, D., 2005. Structural Observations at the Southern dead Sea Transform from Seismic Reflection Data and Aster Satellite Images. Ph.D. Thesis, Universität Potsdam, Scientific Technical Report STR05/04, 98 p.

Klinger, Y., Avouac, J.P., Dorbath, L., Karaki, N.A., Tisnerat, N., 2000. Seismic behaviour of the Dead Sea fault along Arava valley, Jordan. Geophys. J. Int. 142, 769-782.

Lin, A., Tanaka, N., Uda, S., Satish-kumar, M., 2001. Infiltration of Meteoric and Sea Water into Deep Fault Zones during Episodes of Coseismic Events: A Case Study of the Nojima Fault, Japan. Bull. Earthq. Res. Int. 76, 341-353.

Maret, R., Allmendinger, R.W., 1990. Kinematic analysis of fault-slip data. J. Struct. Geol. 12, 973-986.

Mart, Y., Ryan, W.B.F., Lunina, O.V., 2005. Review of the tectonics of the Levant rift system: the structural significance of oblique continetal breakup. Tectonophysics $395,209-232$.

Matar, A., Mascle, G., 1993. Cinematique de la faille du Levant au Nord de la Syrie: analyse microtectonique du fosse d'Alghab. Geodinamica Acta 6 (3), 153-160.

Meghraoui, M., Gomez, F., Sbeinati, R., van der Woerd, J., Mouty, M., Darkal, A.N., Radwan, Y., Layyous, I., Al Najjar, H., Darawcheh, R., Hijazi, F., Al-Ghazzi, R., 
Barazangi, M., 2003. Evidence for 830 years of seismic quiescence from palaeoseismology, archeoseismology and historical seismicity along the Dead Sea fault in Syria. Earth Planet. Sci. Lett. 210, 35-52.

Meyers, W.J., 1978. Carbonate cements: their regional distribution and interpretation in Mississipian limestones of southwestern New Mexico. Sedimentology 25, 371400.

Michael, A.J., 1991. Spatial variations in stress within the 1987 Whittier Narrows, California, aftershock sequence: New techniques and results. J. Geophys. Res. 96, 6303-6319.

Miller, S. A., Nur, A., Olgaard, D.L., 1996. Earthquakes as a coupled shear stress high pore pressure dynamical system. Geophys. Res. Lett. 23, 197-200.

Miller, S. A., 2002. Properties of large ruptures and he dynamical influence of fluids on earthquakes and faulting. J. Geophys. Res. 107(B9), doi: 10.1029/2000JB000032

Moore, D.E., Lockner, D.A., Ito, H., Ikeda, R., 2000. Proceedings of the international workshop on the Nojima fault core and borehole data analysis: U.S. Geological Survey Open-File Report 00-129, 159-165.

Muchez, P., Sintubin, M., 1998. Contrasting origin of palaeofluids in a strike-slip fault system. Chem. Geol. 145, 105-114.

Muhuri, S.K., Dewers, T.A., Scott, T.E., Reches, Z., 2003. Interseismic fault strengthening and earthquake-slip instability: Friction or cohesion? Geology 31, 881-884.

Pe'ri, S., Wdowinski, S., Shtibelman, A., Bechor, N., Bock, Y., Nikolaidis, S., Domselar M., 2002. Current plate motion across the Dead Sea Fault from three years of continuous GPS monitoring. Geophys. Res. Lett. 29, 421-424.

Ponikarov, V.P., 1964. Geological Map of Syria. Ministry of Industry, Damasscus, Syrian Arab Republic. 
Rice, J.R., 1992. Fault stress states, pore pressure distributions, and the weakeness of the San Andreas fault. In: Evans, B., Wong, T. F. (Eds.), Fault mechanics and Transport Properties in Rocks. New York, Academic press, 475-503.

Ritter, O.R., T., Weckmann, U., Hoffmann-Rothe, A., Abueladas, A., Garfunkel, Z., DESERT Research Group, 2003. Geophysical images of the Dead Sea Transform in Jordan reveal an impermeable barririer for fluid flow. Geophys. Res. Lett. 30, doi: 10.1029/2003GL017541.

Rowe, K.J., Rutter, E.H., 1990. Palaeostress estimation using calcite twinning: experimental calibration and application to nature. J. Struct. Geol. 12, 1-17.

Sanlaville, P., Dalongeville, R., Bernier, P., Evin, J., 1997. The Syrian coast: a model of Holocene coastal evolution. J. Coast. Res. 13, 385-396.

Sausse, J., Jacquot, E., Fritz, B., Leroy, J., Lespinase, M., 2001. Evolution of crack permeability during fluid-rock interaction. Example of the Brezouard granite (Vosges, France). Tectonophysics 336, 199-214.

Schulz, S.E., Evans, J.P., 1998. Spatial variability in microscopic deformation and composition of the Punchbowl fault, southern California: implications for mechanisms, fluid-rock interaction, and fault morphology. Tectonophysics 295, 223-244.

Schulz, S.E., Evans, J.P. 2000. Mesoscopic structure of the punchbowl fault, southern California and the geologic and geophysical structure of active strike-slip fault. J. Struct. Geol. 22, 913-930.

Sibson, R.H., 1977. Fault rocks and fault mechanisms. J. Geol. Soc. Lond. 133, 191213.

Sibson, R.H., 1992. Implications of fault-valve behaviour for rupture nucleation and recurrence. Tectonophysics 211, 283-293. 
Sleep, N.H., Blanpied., M.L., 1992. Creep, compaction and the weak rheology of major faults. Nature 359, 687-692.

Stewart, I.S., Hancock, P.L., 1994. Neotectonics. In Hancock (Ed.) Continental deformation. Pergamon Press, 370-409.

Verhaert, G., Muchez, P., Sintubin, M., Similox-Tohon, D., Vandycke, S., Keppens, E., Hodge, E.J., Richards, D.A., 2004. Origin of palaeofluids in a normal fault setting in the Aegean region. Geofluids 4, 300-314.

Wdowinski, S., Zilberman, E., 1997. Systematic analyses of the large-scale topographic and structure across the Dead Sea Rift. Tectonics 16, 409-424.

Westaway, R., 2004. Kinematic consistency between the Dead Sea Fault zone and the Neogene and Quaternary left-lateral faulting in SE Turkey. Tectonophysics 391, 203-237.

Wibberley, C.A.J., Shimamoto, T., 2003. Internal structure and permeability of major strike-slip fault zones: the median tectonic Line in Mie Prefecture, southwest Japan. J. Struct. Geolog. 25, 53-78.

Wu, S., 1993. Microstructures, deformation mechanisms and strain patterns in a verticale profile, inner Appalachian fold-thrust belt, Alabama. J. Struct. Geol. 15, $129-144$.

Zanchi, A., Crosta, G.B., Darkal, A.N., 2002. Paleostress analyses in NW Syria: constraints on the Cenozoic evolution of the northwestern margin of the Arabian plate. Tectonophysics $357,255-278$. 


\section{Figures}

Figure 1. Regional setting of the Dead Sea Transform with fault segments discussed in this paper. AF: Arava Fault segment; SF: Serghaya Fault segment; GF: Ghab fault segment; YF: Yammouneh Fault (not investigated)

Figure 2. Satellite image and simplified geological maps of the fault segments investigated in detail (a) Arava Fault with areas of detailed investigations. AF=locations, A=samples number (after Jansen et al., 2005). (b) Serghaya Fault with locations ( $\mathrm{SF}=$ locations; based on geological map of Ponikarov 1964). (c) Ghab Fault with locations (GF=locations; based on geological map of Ponikarov 1964).

Figure 3. Photographs of fault-related deformation structures along AF, SF and GF.

(a) Central Arava Valley (AF) with pressure ridges. (b) Displaced aqueduct with a total left-lateral offset of about $13.6 \mathrm{~m}$ crossing the GF (see also Meghraoui et al. 2003). (c) Displaced drainage crossing the SF (see also Gomez et al. 2003). (d) Foliation in the scaly mudstone matrix of the SF. (e) Friable fault breccias of the AF (scale: $20 \mathrm{~cm}$ ). (f) $\mathrm{SF}$ with unconsolidated alteration zone (fault core). (g) Cemented fault breccia of the SF. (h) Normal faults in Upper Triassic dolostones of the GF.

Figure 4. Results of structural analysis (meso- and microstructures) along a profile normal to the Serghaya Fault (location SF4 in Fig. 2b). (a) Number of fractures, subsidiary faults and veins per meter. (b) Fault zone with fault core and damage zone. (c) Percentages of microstructures and estimated temperatures and magnitudes of differential stress. S4-S8 = samples point 
Figure 5. Results of the kinematic analysis. (a) Arava Fault. Left: fault planes and fault slip data. Middle: Distribution of kinematic shortening ( $\mathrm{P}$ axes; red) and extension ( $\mathrm{T}$ axes; blue) axes. Right: Pseudo focal mechanism solution. The white quadrants contain the compression axis (1) and the red quadrants contain the extension axis (3) (b) Serghaya Fault (as Fig 5a). (c) Ghab fault (as Fig 5a). (d) Summary of the results of the kinematic analysis for the three fault segments and additional results of stress tensor inversion for the entire data base. $\mathrm{R}=$ relative stress magnitude

Figure 6. Photomicrographs of microstructures under crossed nicols (left) and CLphotographs (right) of the same region. (a-b) Vein cement with growth zones visible as different CL-colors. (c-d) Fault breccia. Note the differences in CL-colors between matrix and clasts. (e-f) Contact area between undeformed vein cement and matrix. Note that vein cement and surrounding matrix luminescence in the same intrinsic blue color. (g-h) Sedimentary matrix and two generations of calcite veins. (i-j) Vein dolomite with growth zones visible as different CL-colors.

Figure 7. Results of microstructural analysis. Columns represent the normalized percentages of selected microstructures (fractures, twins, pressure solution), unfaulted matrix and unfaulted cement. The estimated temperatures and magnitudes of differential stress are shown in the rectangles (a) Fault rock samples from the Arava fault. Area A: samples collected from pressure ridges. Area $B$ : samples from a profile perpendicular to the fault. (b) Fault rock samples from the Serghaya fault. Note that younger calcites (latest vein generation) in sample S2, S4 S5 are not twinned (c) Fault rock samples from the Ghab fault (vein dolomite: G15-G21, G27-G31, G33; vein calcite: G22-G26, G32, G34). 
Figure 8. Graph of cataclastic fabric (\%) plotted against undeformed cement (\%). The ratio between cataclastic fabric and und vein cement shows the predominance of fluid-assisted healing processes in the SF and GF segments

Figure 9. Conceptual model of fault evolution (modified after Sibson 1992). (a) Cyclic development of faulting processes in the SF and GF segment leading to shorter earthquake recurrence intervals than in the AF segment. (b) Lack of cementation in the AF segment prevents the creation of elevated pore pressure and as a consequence the earthquake recurrence intervals are longer than in the SF and GF segment.

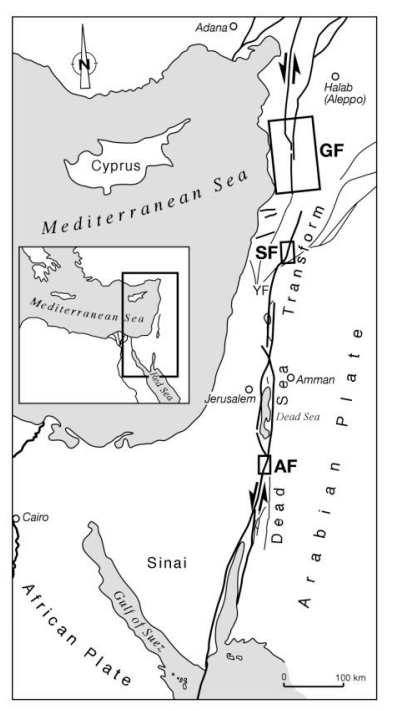

Fig. 1 


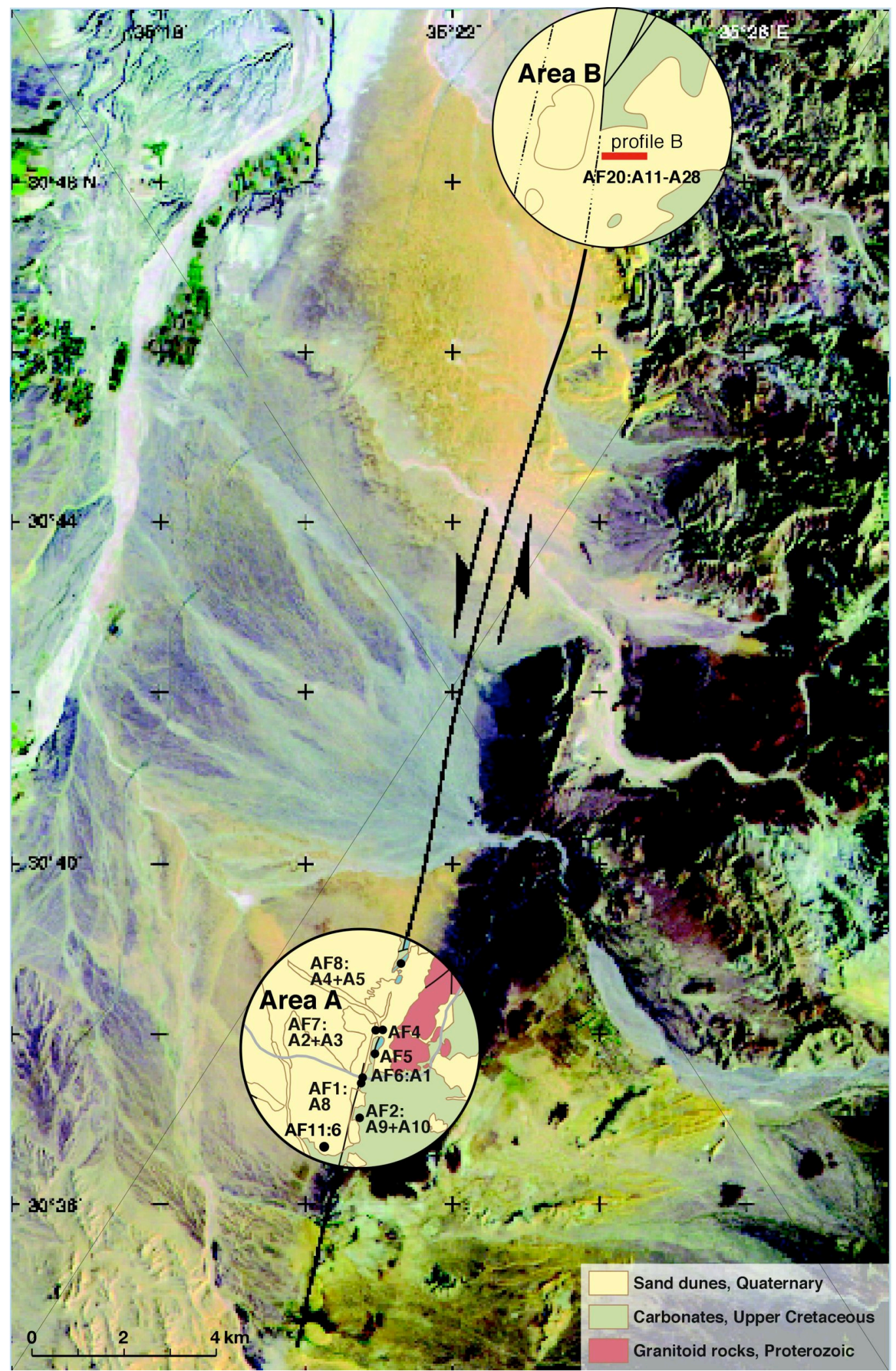

Fig. 2a 

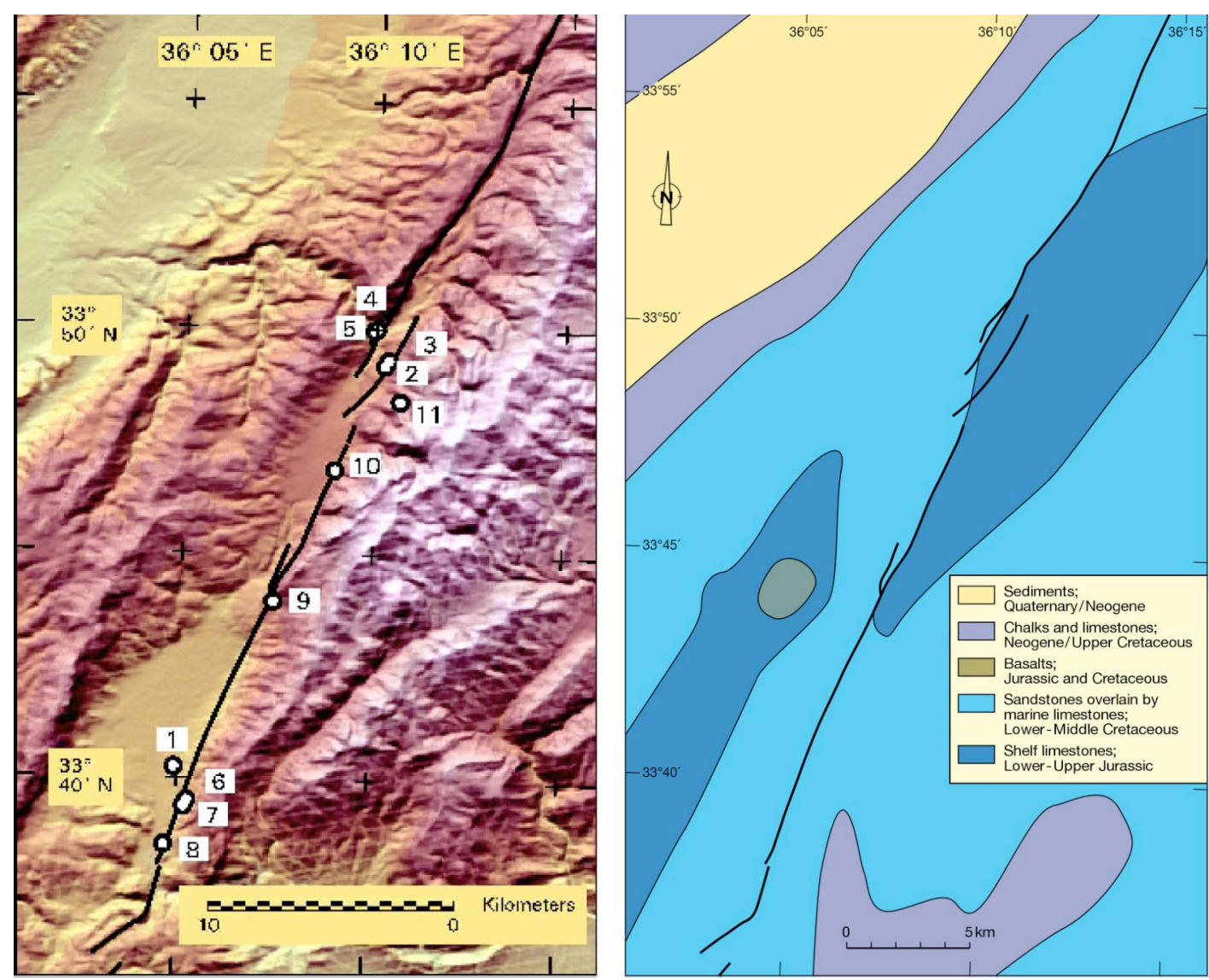

Fig. 2b
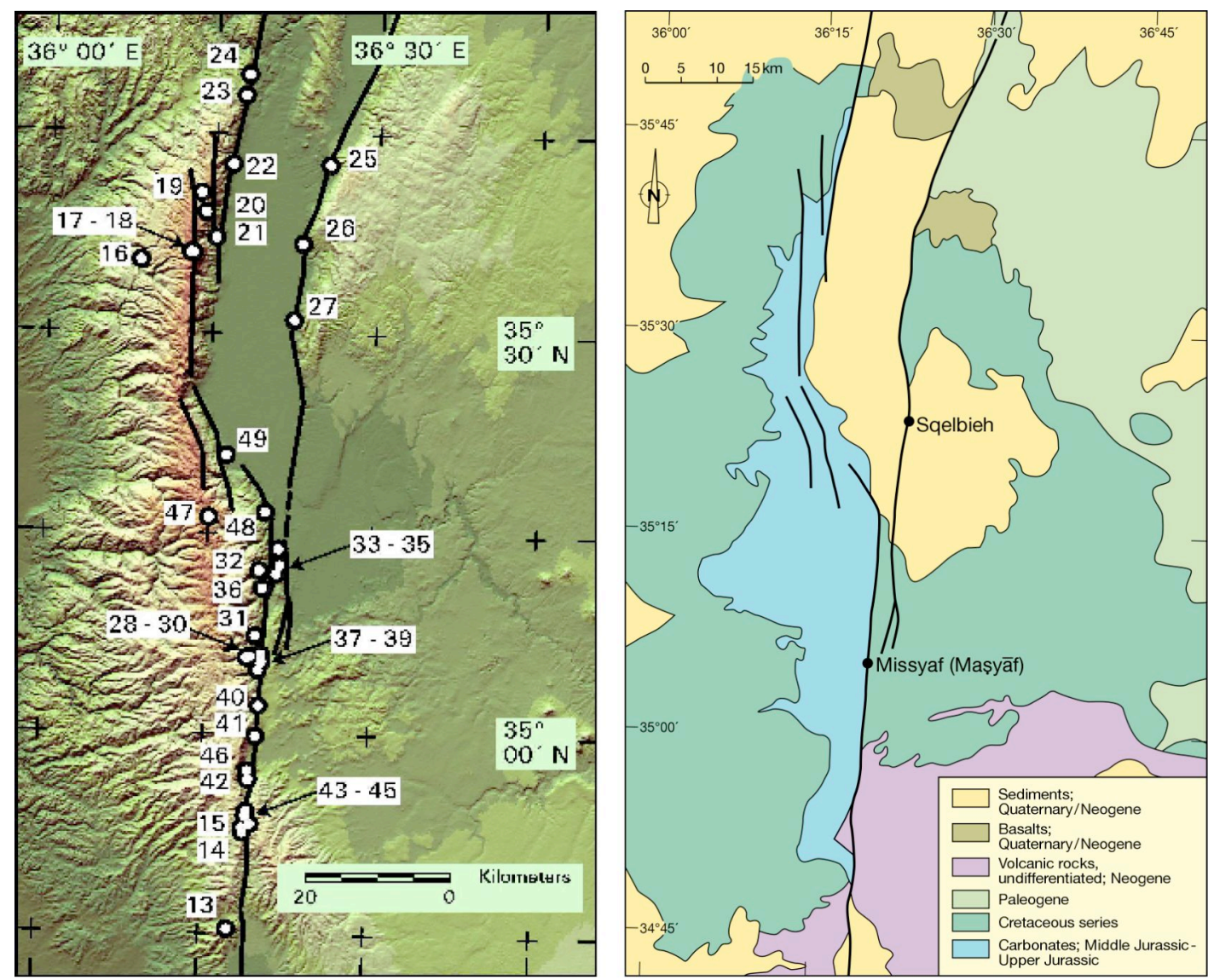

Fig. 2c 


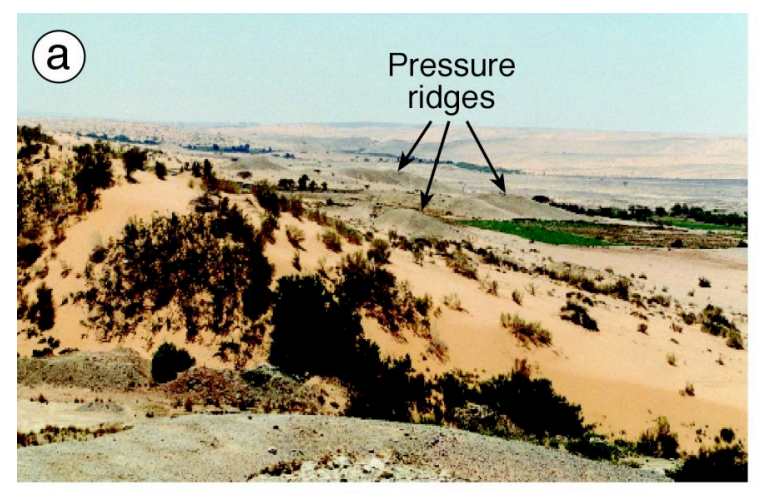

(c)
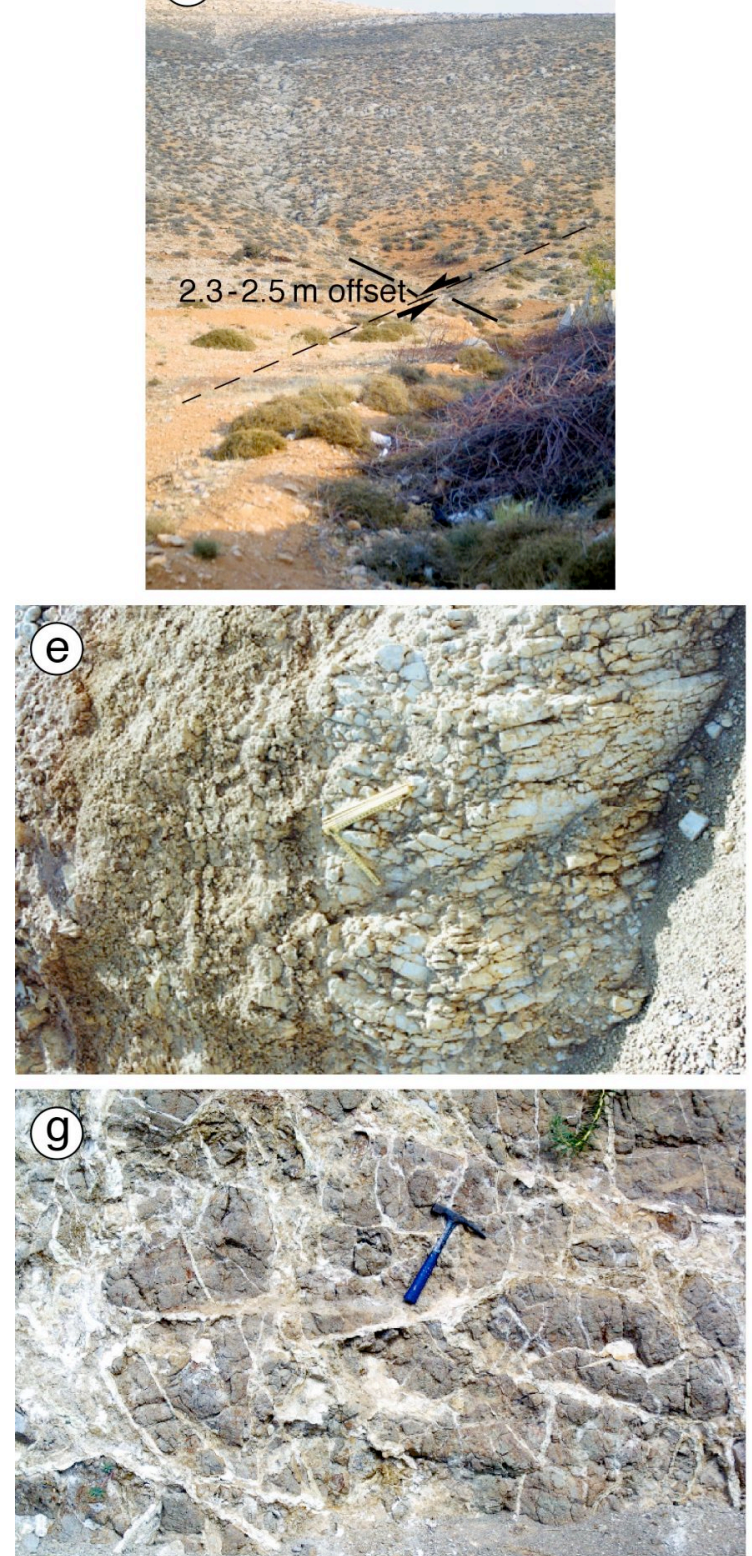
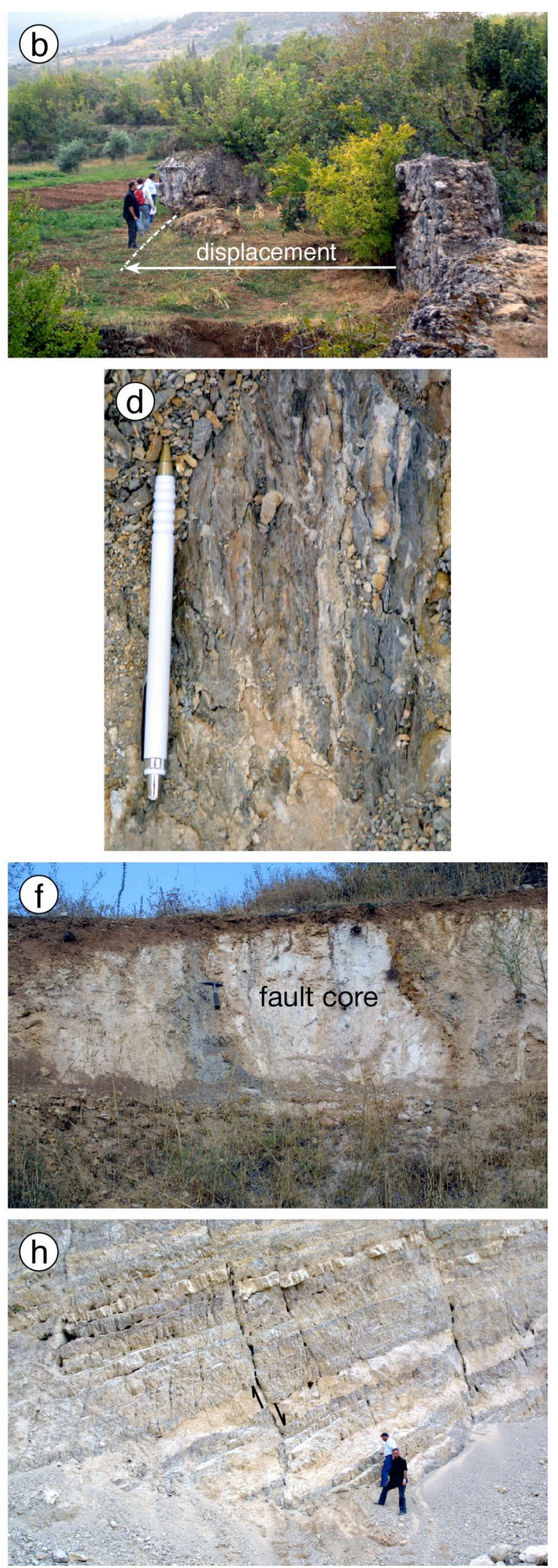

Fig. 3 
a)

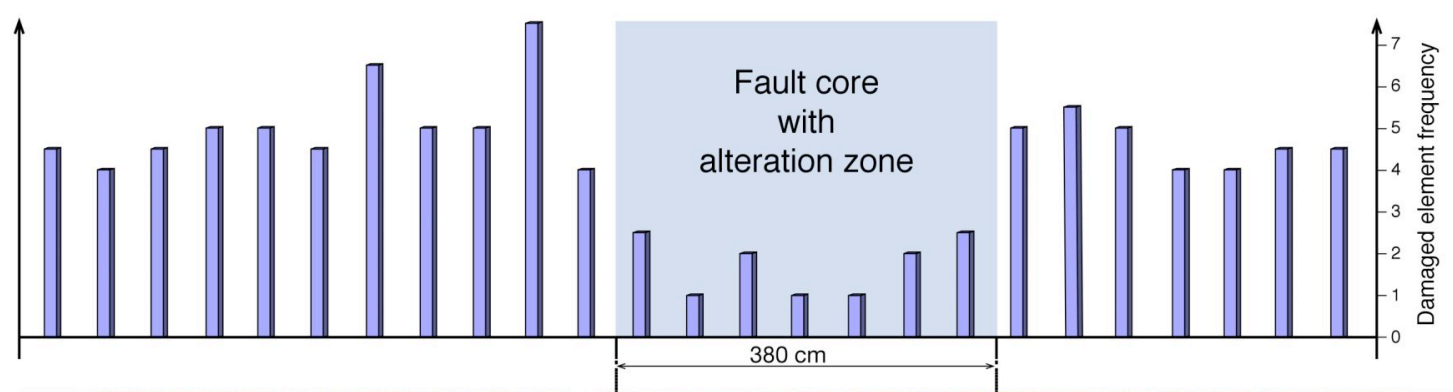

b) sw.

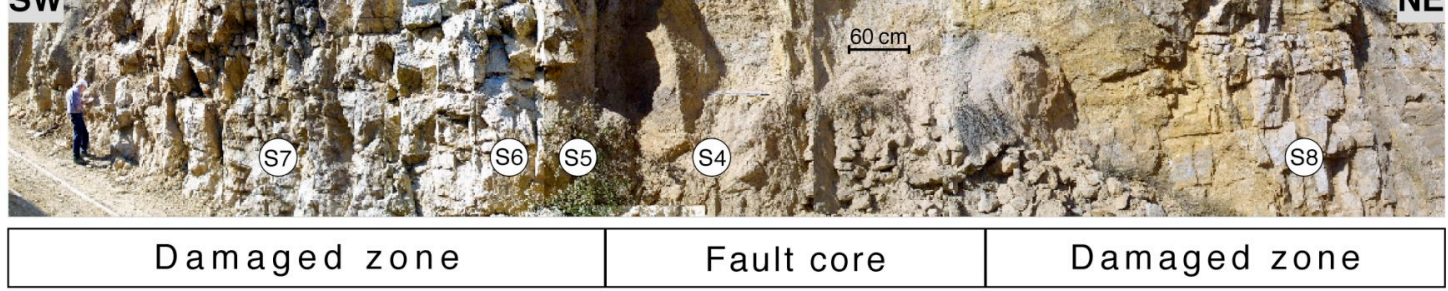

C)
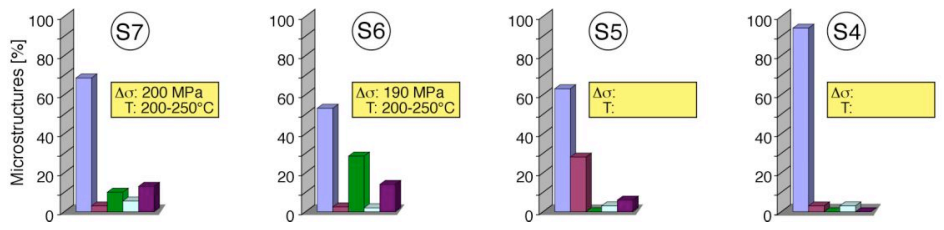

$\square$ unfaulted matrix $\square$ fractures

deformation twins

$\square$ pressure solution

$\square$ undeformed cement

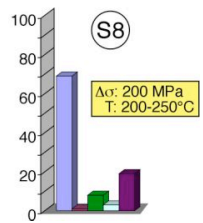

Fig. 4 


\section{Araba Fault}
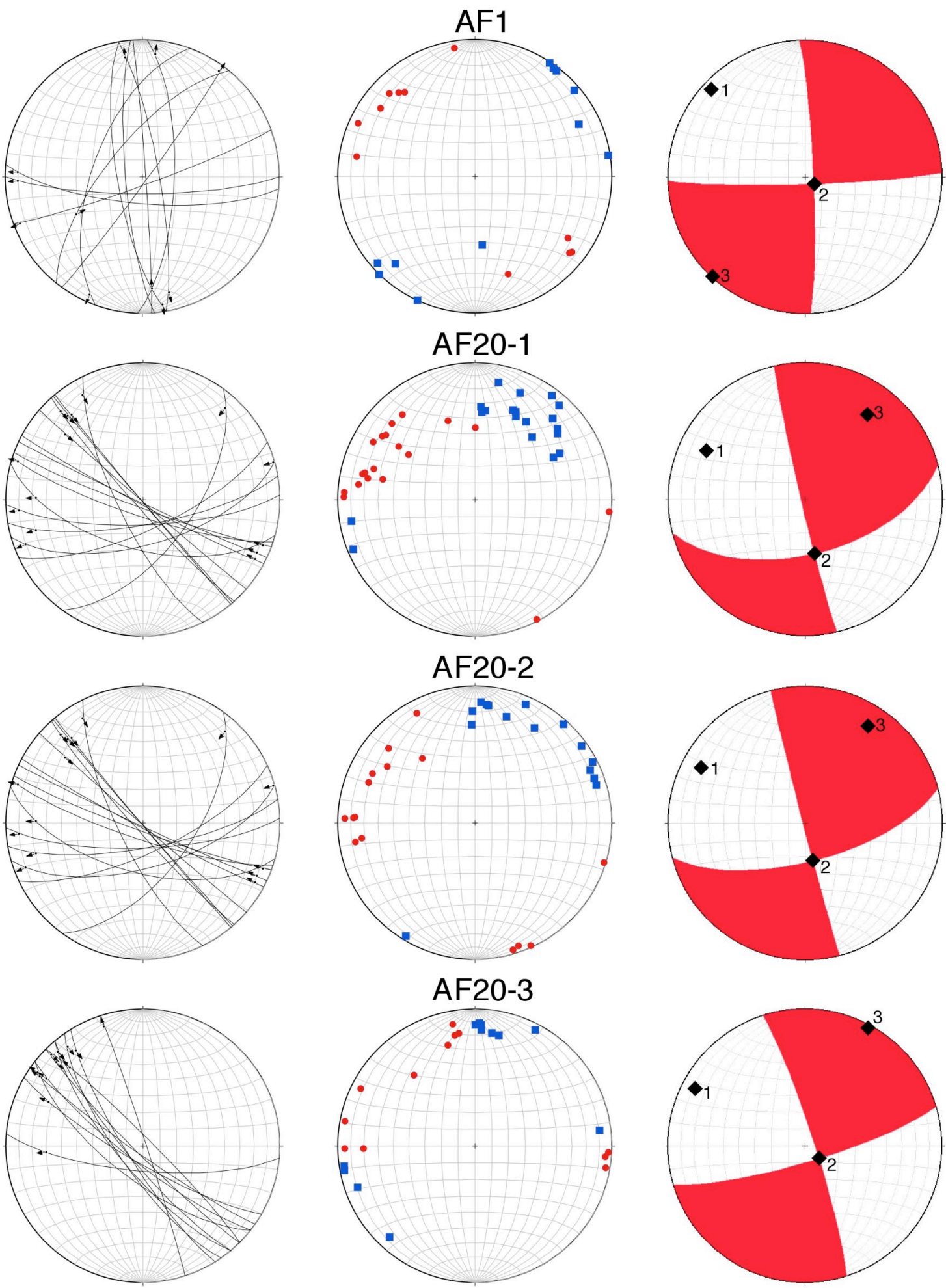

Fig.5a 
Serghaya Fault
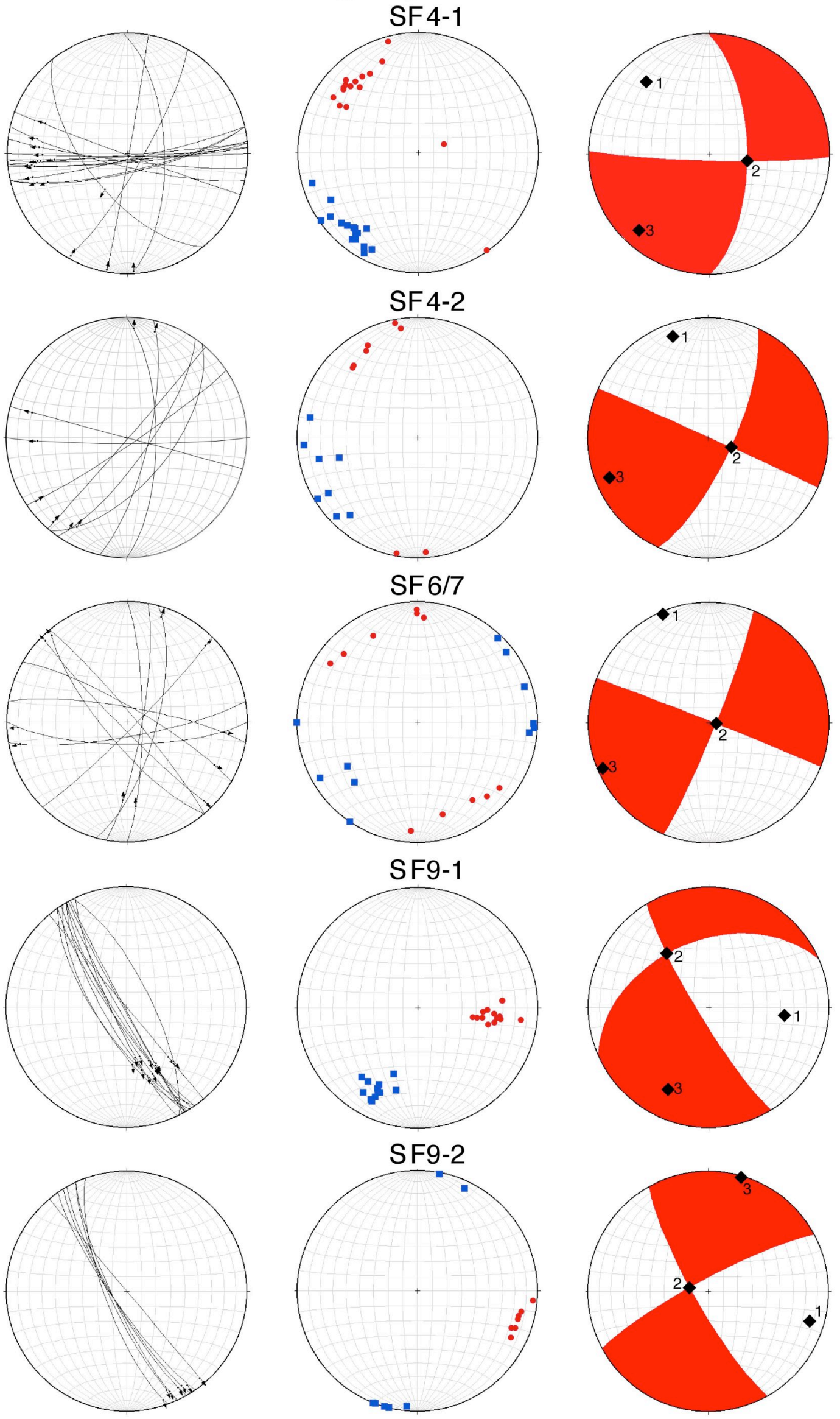

Fig.5b 
(c)

Ghab Fault
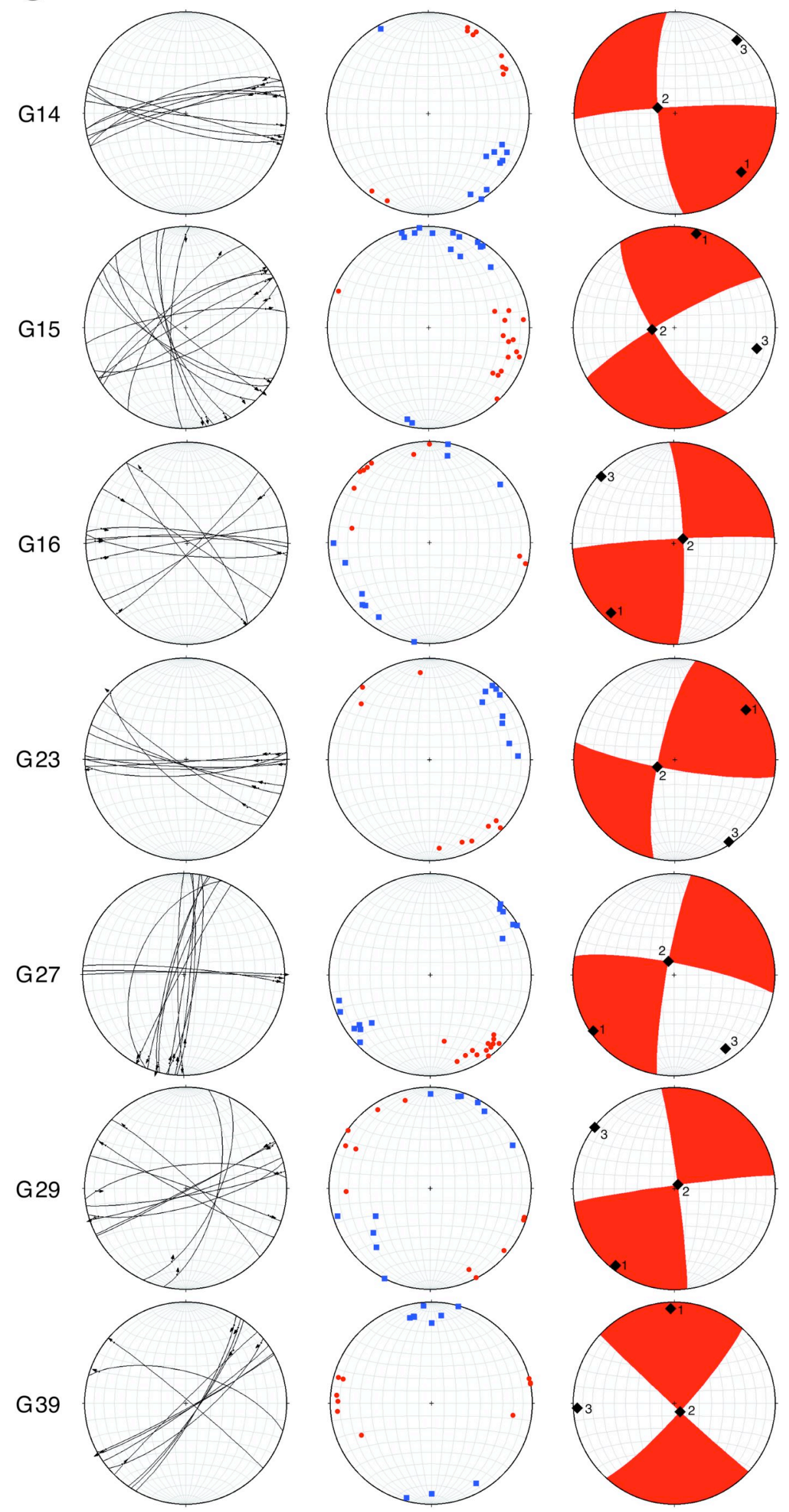

Fig. 5c 
(d)
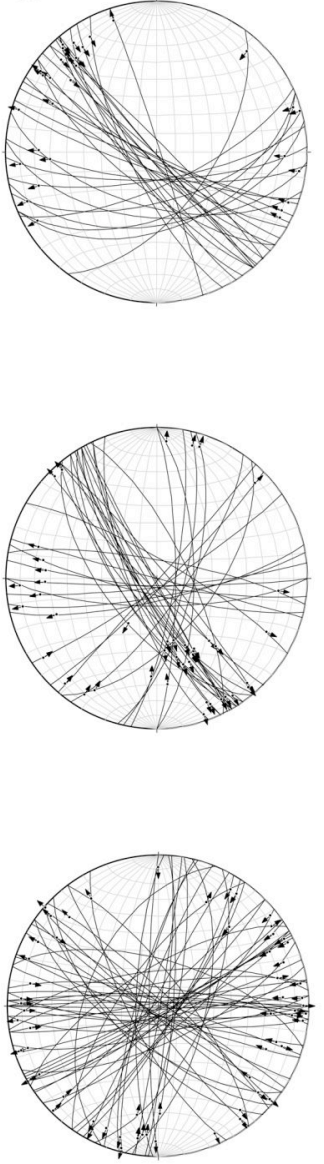

Fig. 5d

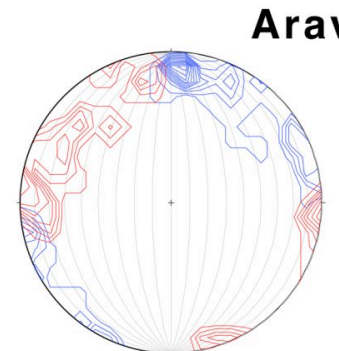

$1 \%$ Area Contour of T-Axes $1 \%$ Area Contour of P-Axes

\section{Serghaya Fault}
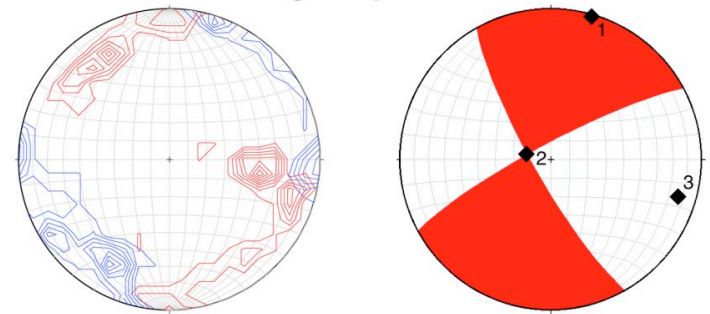

\section{Yammouneh Fault}

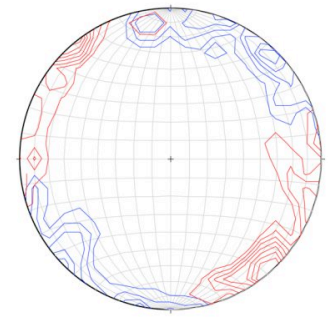

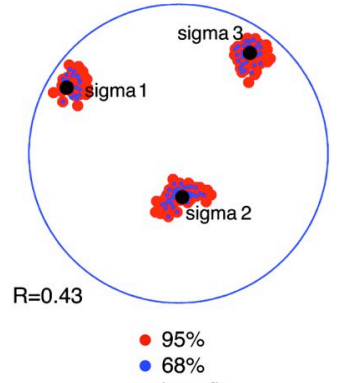

- best fit

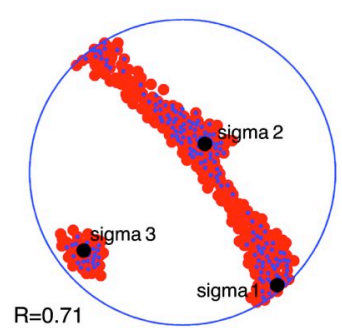

$\mathrm{R}=0.71$

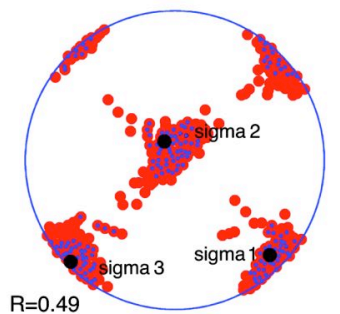



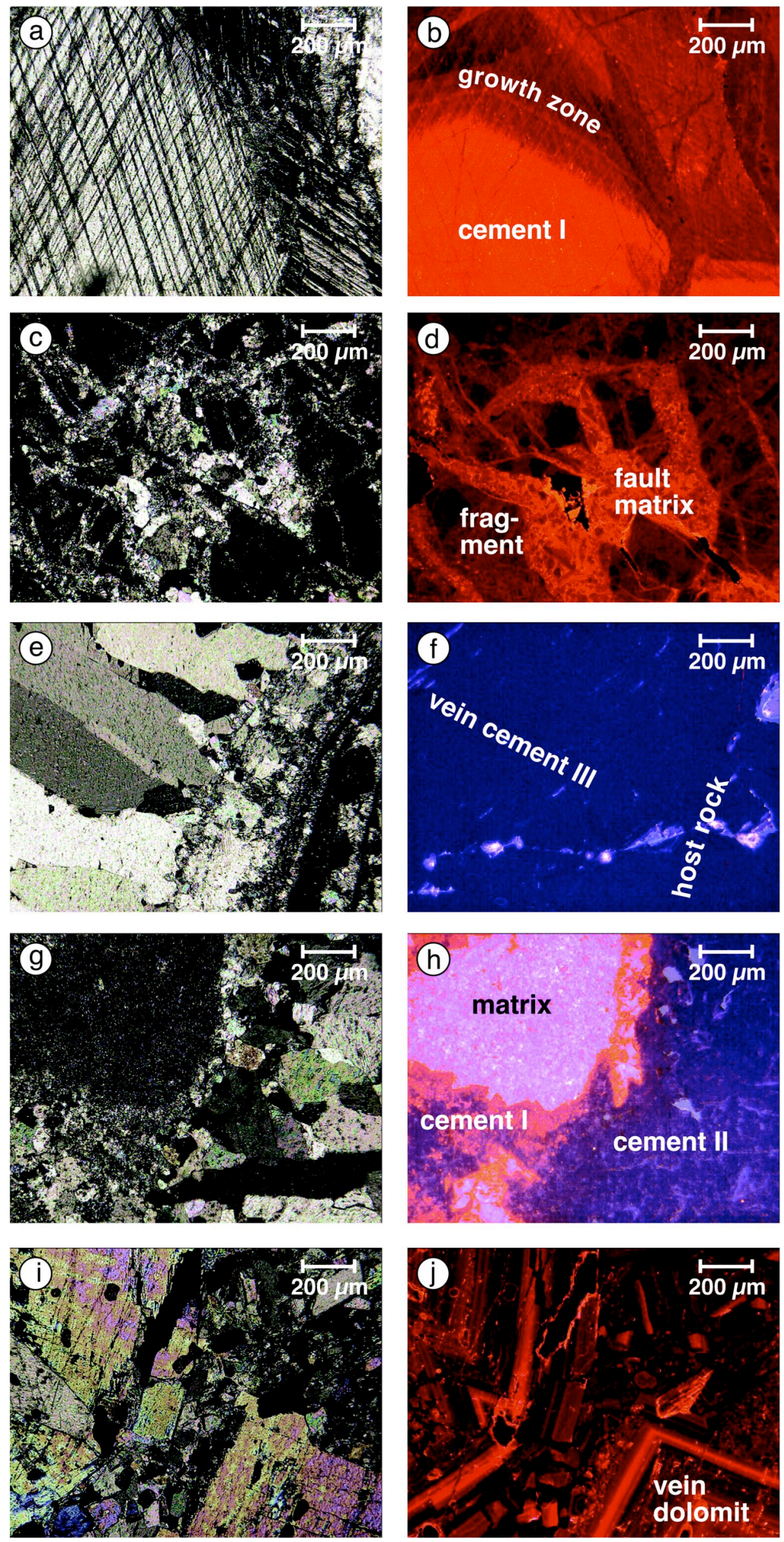

Fig. 6 
(a)
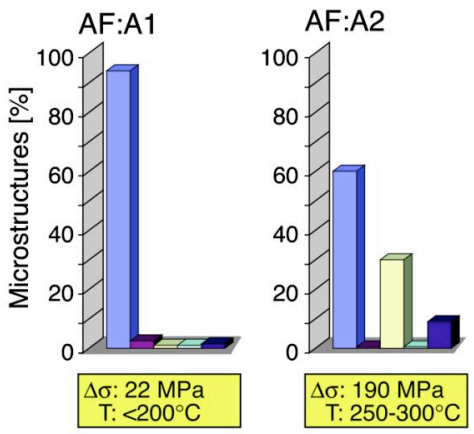

Arava Fault
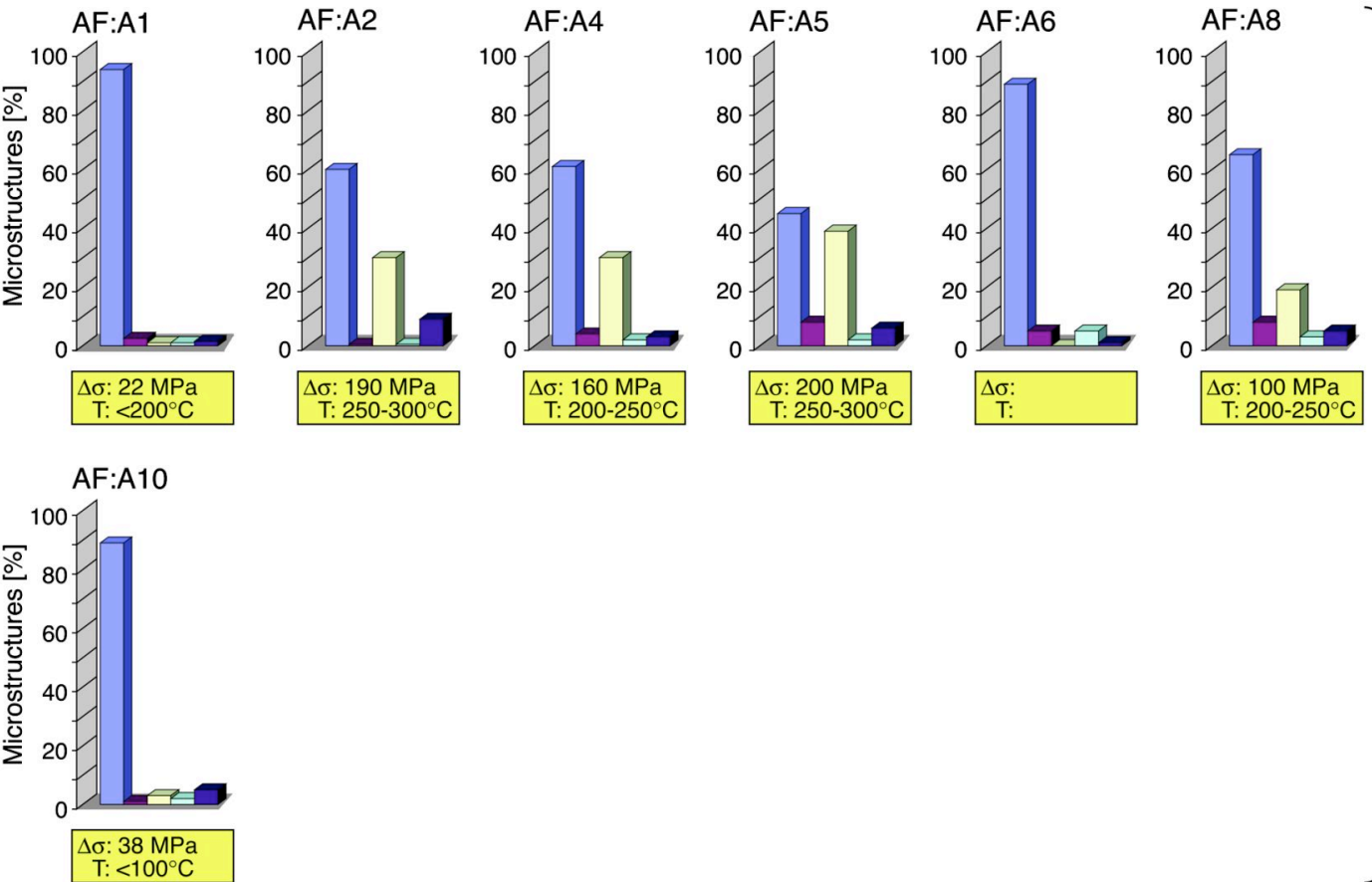

$\varangle$
$\frac{1}{4}$
$\frac{1}{4}$
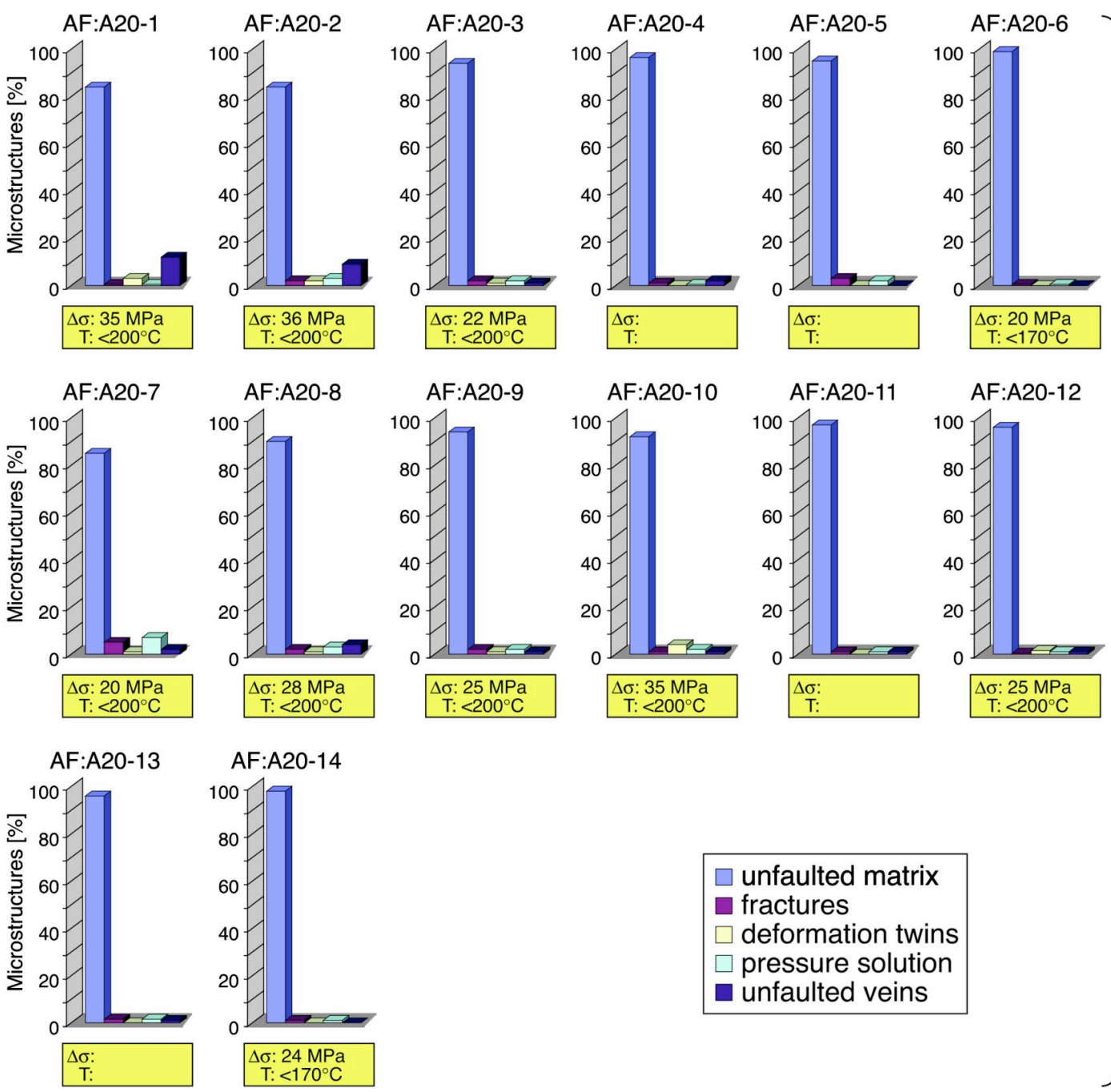

AF:A20-14
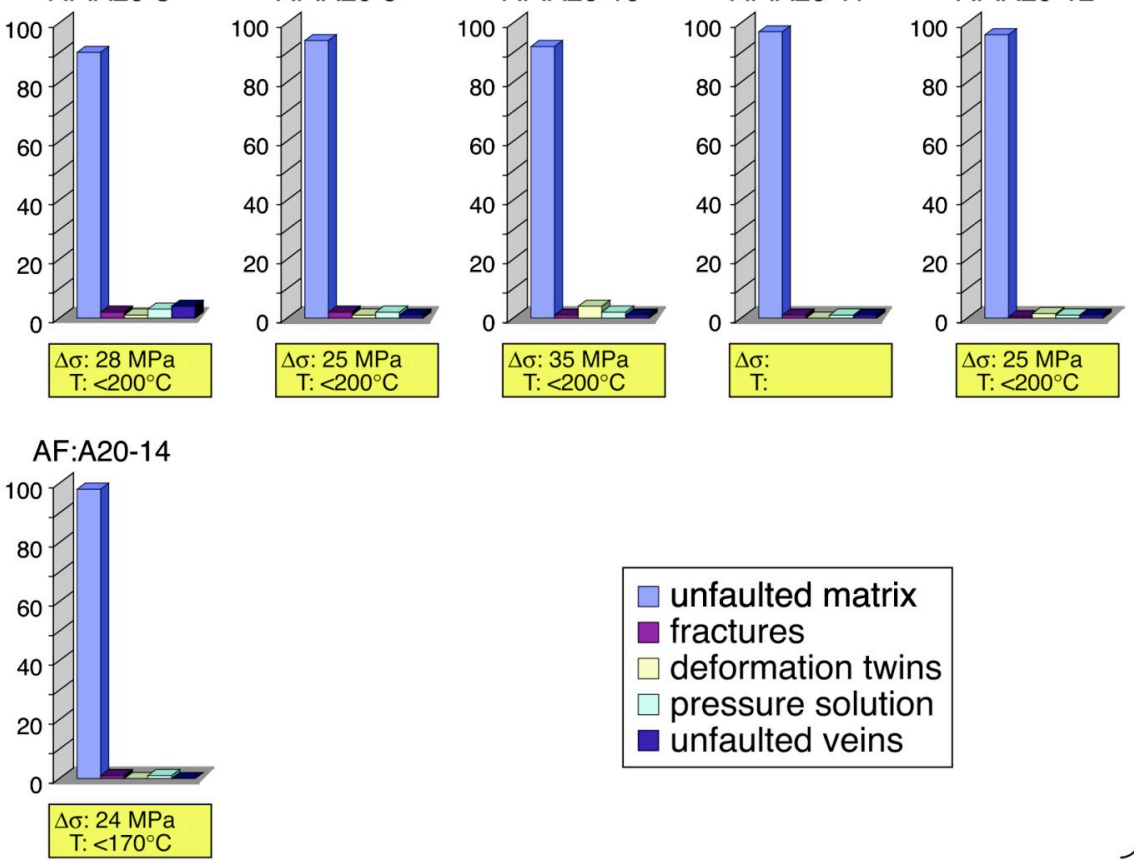

0
0
0
$\frac{1}{4}$

Fig.7a 
(b)

\section{Serghaya Fault}
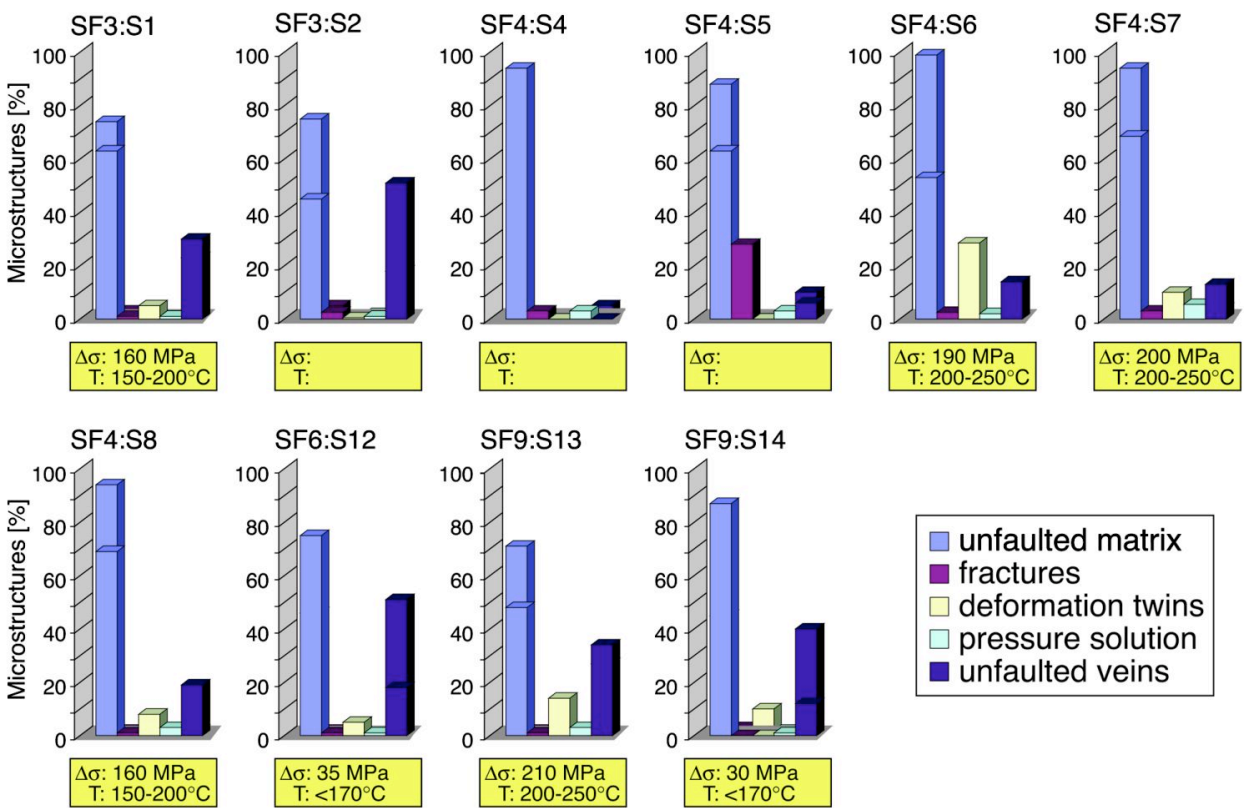

$\square$ unfaulted matrix

$\square$ fractures

$\square$ deformation twins

$\square$ pressure solution

- unfaulted veins

Fig. $7 b$ 
(c)

Ghab Fault
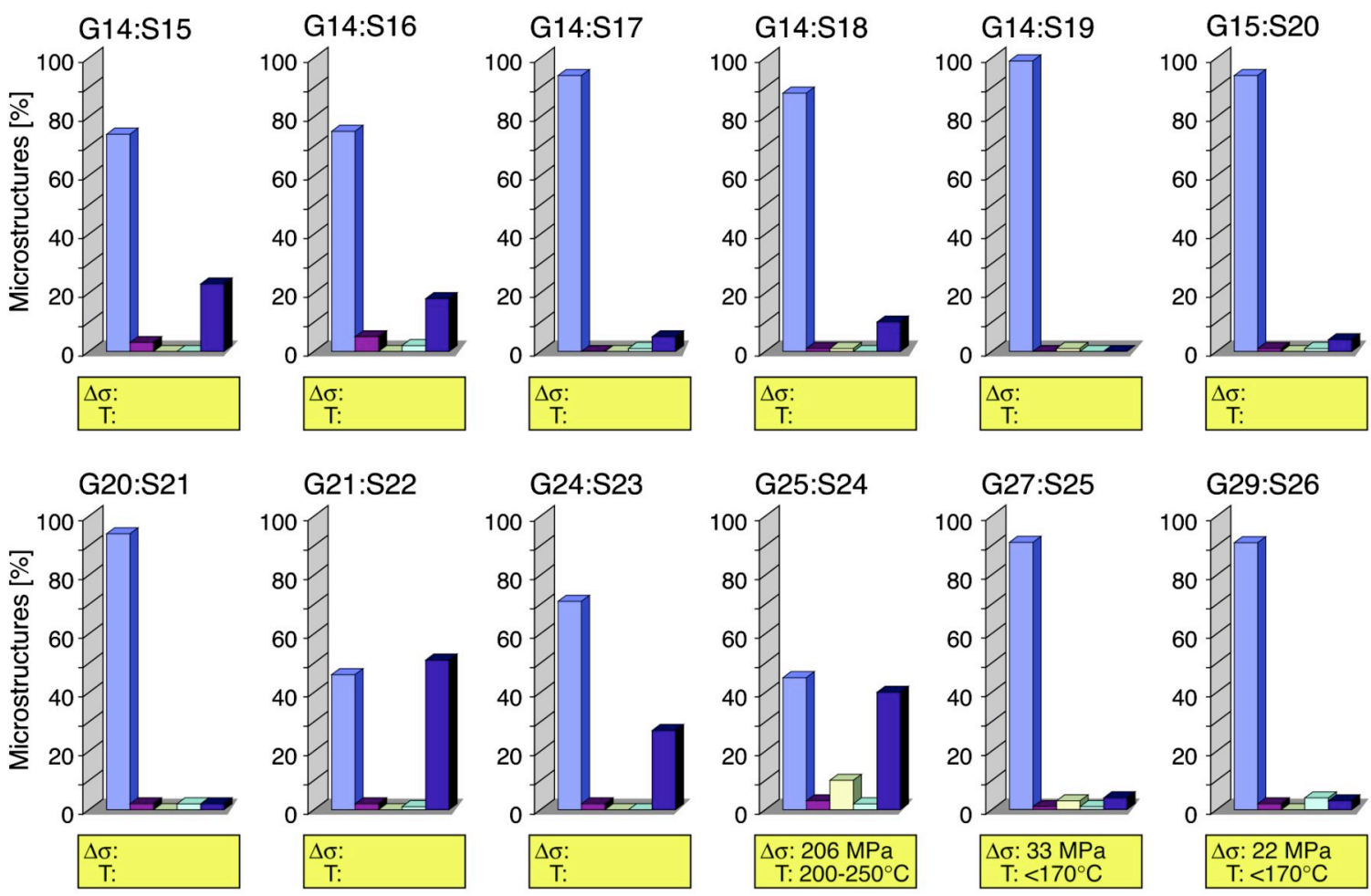

G29:S26
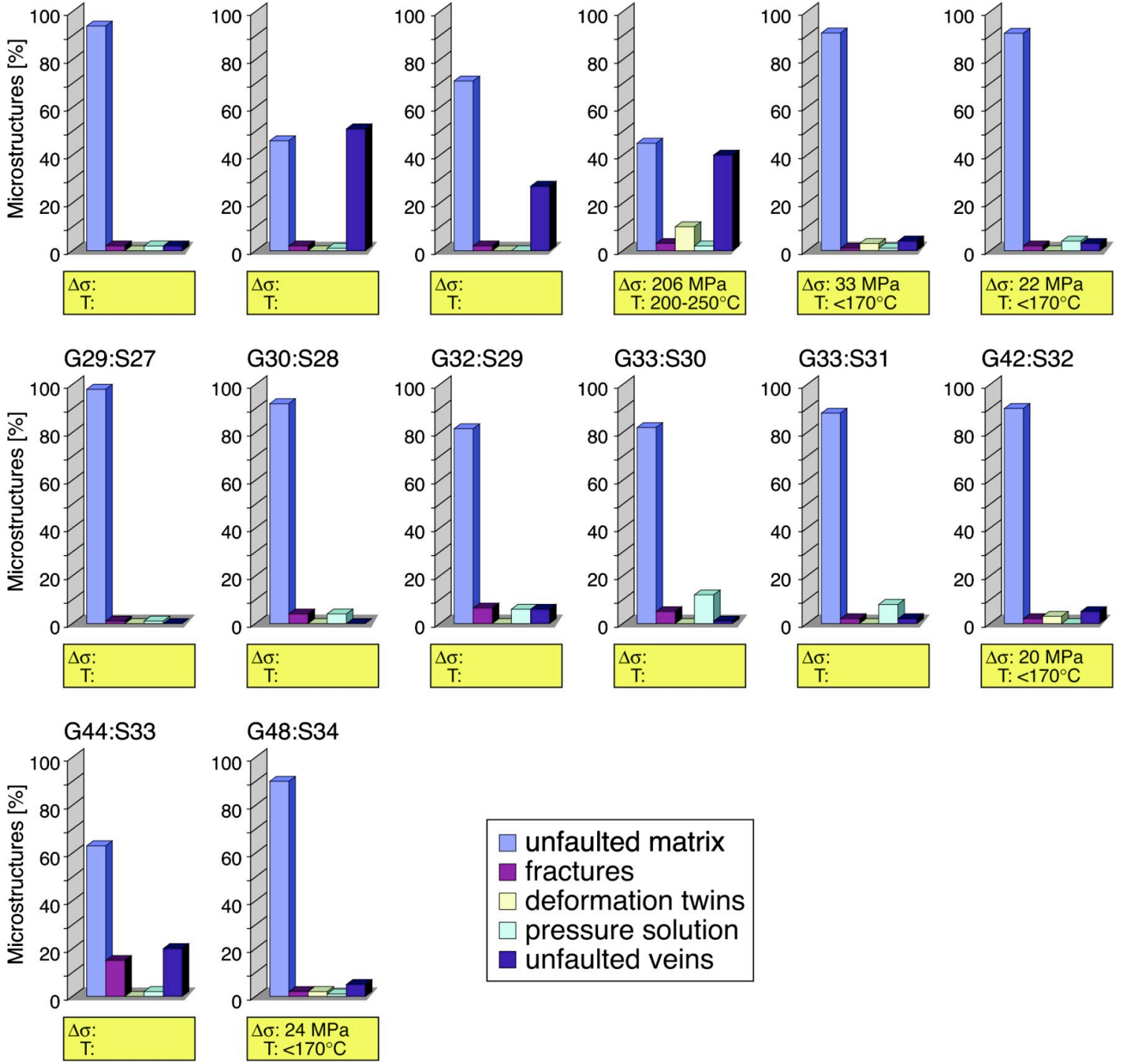

Fig. 7c 


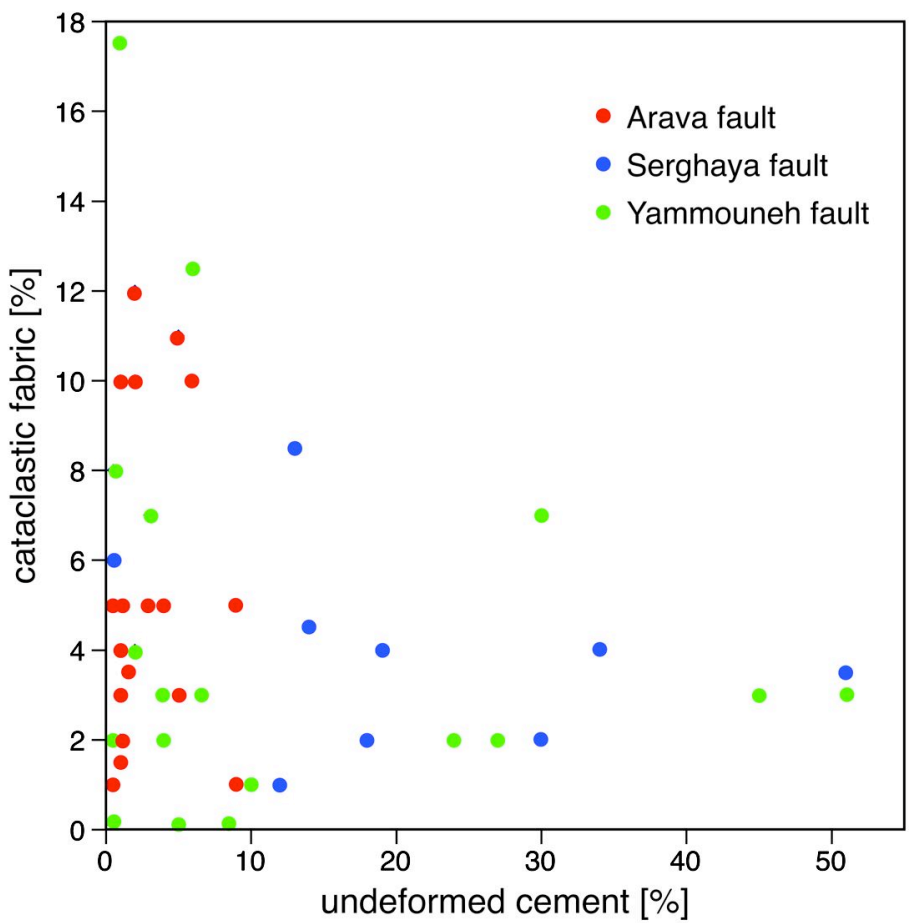

Fig. 8 


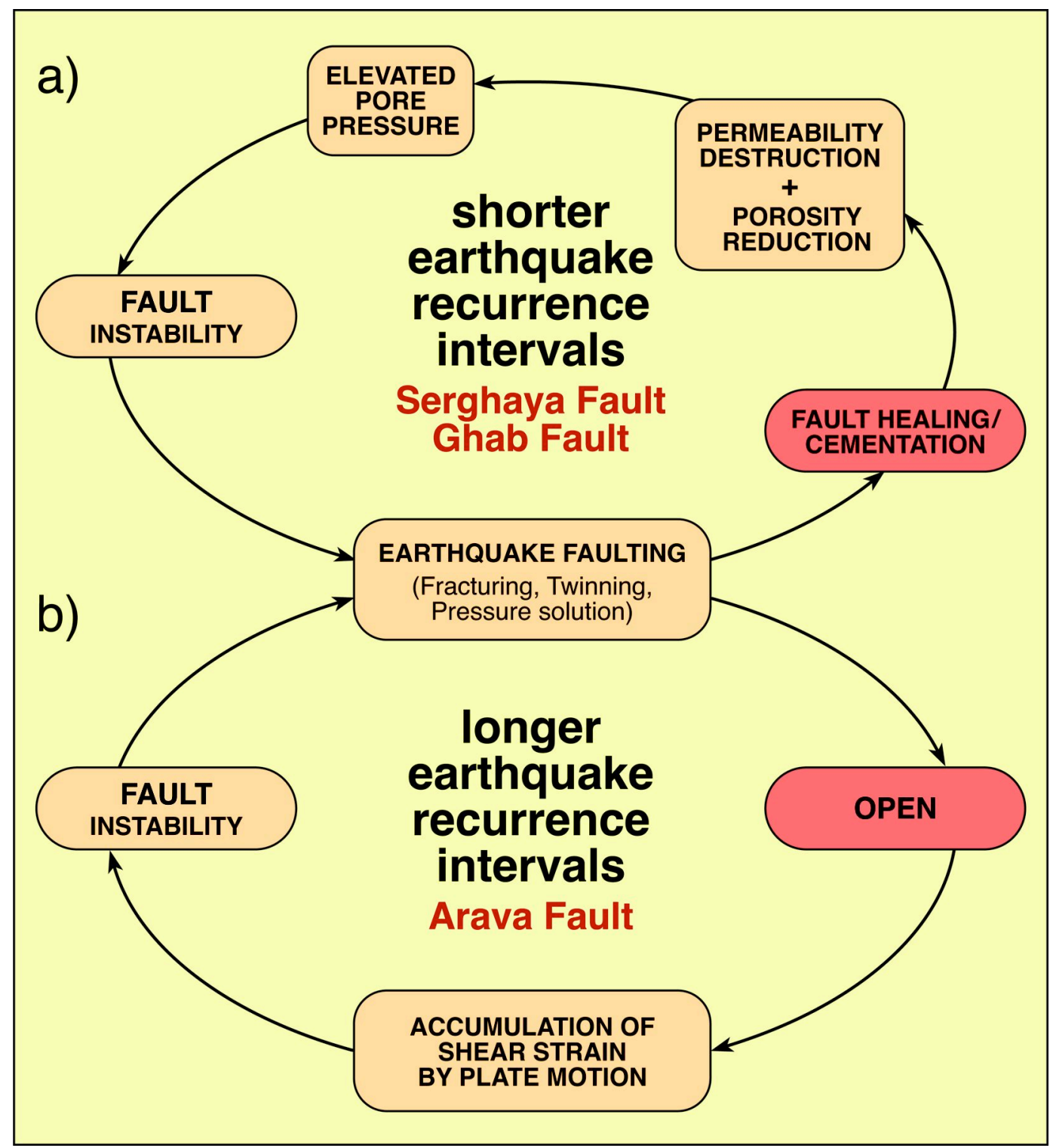

Fig. 9 


\section{Tables}

Table 1. Description of thin sections, with a note on mineralogy, cement type, microstructures and derived deformation conditions.

\begin{tabular}{|c|c|c|c|c|c|c|}
\hline $\begin{array}{l}\text { Stage of fault } \\
\text { cementation }\end{array}$ & Segment & $\begin{array}{l}\text { Cement } \\
\text { Compo- } \\
\text { sition }\end{array}$ & $\begin{array}{l}\text { Cement } \\
\text { type }\end{array}$ & $\begin{array}{l}\text { CL- } \\
\text { observation }\end{array}$ & $\begin{array}{c}\text { Micro- } \\
\text { structures }\end{array}$ & $\mathrm{T}, \Delta \delta$ \\
\hline $\begin{array}{l}\text { I; older } \\
\text { cementation }\end{array}$ & $\begin{array}{l}\text { AF, SF } \\
\text { (GF, only } \\
\text { one sample) }\end{array}$ & calcite & $\begin{array}{l}\text { large blocky } \\
\text { and fibrous } \\
\text { calcite } \\
\text { cement }\end{array}$ & $\begin{array}{l}\text { CL-contrast bet- } \\
\text { ween cement and } \\
\text { enclosing matrix }\end{array}$ & $\begin{array}{l}\text { heavily } \\
\text { twinned, } \\
\text { thick and } \\
\text { curved twin } \\
\text { lamellae }\end{array}$ & $\begin{array}{l}150^{\circ} \mathrm{C}- \\
300^{\circ} \mathrm{C} ? \\
\text { up to } \\
200 \\
\mathrm{MPa}\end{array}$ \\
\hline $\begin{array}{l}\text { II; late } \\
\text { cementation }\end{array}$ & $\mathrm{AF}, \mathrm{SF}, \mathrm{GF}$ & calcite & $\begin{array}{l}\text { mosaic } \\
\text { calcite } \\
\text { cement }\end{array}$ & $\begin{array}{l}\text { bright CL-colors } \\
\text { in cement and } \\
\text { host rock }\end{array}$ & $\begin{array}{l}\text { less } \\
\text { twinned, } \\
\text { thin twin } \\
\text { lamellae }\end{array}$ & $\begin{array}{l}<170^{\circ} \mathrm{C} \\
20- \\
30 \mathrm{MPa}\end{array}$ \\
\hline $\begin{array}{l}\text { III; latest } \\
\text { cementation }\end{array}$ & SF, GF & calcite, & $\begin{array}{l}\text { elongated } \\
\text { fibrous } \\
\text { calcites }\end{array}$ & do not luminesce & $\begin{array}{l}\text { not twinned } \\
\text { and } \\
\text { fractured }\end{array}$ & $\begin{array}{l}\text { sub- } \\
\text { surface } \\
\text { con- } \\
\text { ditions }\end{array}$ \\
\hline $\begin{array}{l}\text { IV dolomite } \\
\text { cementation }\end{array}$ & GF & dolomite & $\begin{array}{l}\text { coarse } \\
\text { dolomite } \\
\text { cement and } \\
\text { scalenohedral } \\
\text { dolomite } \\
\text { cement }\end{array}$ & $\begin{array}{l}\text { growth zones } \\
\text { with different } \\
\text { CL-colors }\end{array}$ & fractured & $<50^{\circ} \mathrm{C}$ ? \\
\hline
\end{tabular}


Table 2. Comparison of selected fault segments.

\begin{tabular}{|c|c|c|c|c|c|c|c|}
\hline \begin{tabular}{|l|} 
Fault \\
segment
\end{tabular} & $\begin{array}{l}\text { Slip- } \\
\text { rate }^{1,2,3}\end{array}$ & $\begin{array}{l}\text { Displa- } \\
\text { cement }^{1,2}\end{array}$ & Earthquakes $^{3}$ & $\begin{array}{l}\text { Earthquake } \\
\text { recurrence }\end{array}$ & $\begin{array}{l}\text { Fault } \\
\text { architecture }\end{array}$ & Kinematic & $\begin{array}{l}\text { Fluid-rock } \\
\text { interaction }\end{array}$ \\
\hline $\begin{array}{l}\text { Arava } \\
\text { Segment } \\
160 \mathrm{~km}\end{array}$ & $\begin{array}{l}4.0 \\
\pm 2.0 \\
\mathrm{~mm} / \mathrm{yr}\end{array}$ & $105 \mathrm{~km} ?$ & $\begin{array}{l}\text { active } \\
\text { AD } 1068 \\
\text { AD } 1293 \\
\text { AD } 1458\end{array}$ & $\begin{array}{l}\sim 2800 \mathrm{yr}^{4} \\
1500 \mathrm{yr}^{5} \\
11000 \mathrm{yr}^{6} \\
10000- \\
14000 \mathrm{yr}^{7}\end{array}$ & $\begin{array}{l}\text { no typical } \\
\text { fault zone } \\
\text { architecture }\end{array}$ & $\begin{array}{l}\text { NW-SE } \\
\text { compression } \\
\text { sinistral } \\
\text { Strike-slip }\end{array}$ & $\begin{array}{l}\text { negligible } \\
\text { fluid-rock } \\
\text { interactions }\end{array}$ \\
\hline $\begin{array}{l}\text { Serghaya } \\
\text { Segment } \\
125 \mathrm{~km}\end{array}$ & $\begin{array}{l}1.4 \\
\mathrm{~mm} / \mathrm{yr}\end{array}$ & $?$ & $\begin{array}{l}\text { active } \\
\text { BC } 198 \\
\text { AD } 115 \\
\text { AD } 303 \\
\text { AD } 551 \\
\text { AD } 749 \\
\text { AD } 991 \\
\text { AD } 1202 \\
\text { AD } 1705 \\
\text { AD } 1759 \\
\text { AD } 1837\end{array}$ & $1300 \mathrm{yr}^{3}$ & $\begin{array}{l}\text { fault core } \\
\text { and } \\
\text { damage } \\
\text { zone } \\
\text { exposed }\end{array}$ & $\begin{array}{l}\text { NW-SE } \\
\text { compression, } \\
\text { strike slip } \\
\text { with an } \\
\text { extensional } \\
\text { component }\end{array}$ & $\begin{array}{l}\text { intensive } \\
\text { fluid-rock } \\
\text { interactions }\end{array}$ \\
\hline $\begin{array}{l}\text { Ghab } \\
\text { Segment } \\
140 \mathrm{~km} ?\end{array}$ & $\begin{array}{l}6.9 \\
\mathrm{~mm} / \mathrm{yr}\end{array}$ & $\begin{array}{l}20-25 \\
\mathrm{~km} \text { since } \\
\text { latest } \\
\text { Miocene }\end{array}$ & $\begin{array}{l}\text { active, } \\
\text { AD } 115 \\
\text { AD } 859 \\
\text { AD } 1157 \\
\text { AD } 1170 \\
\text { AD } 1408\end{array}$ & $1400 \mathrm{yr}^{5}$ & $\begin{array}{l}\text { damage } \\
\text { zone } \\
\text { exposed }\end{array}$ & $\begin{array}{l}\text { NW-SE } \\
\text { compression } \\
\text { sinistral } \\
\text { strike-slip }\end{array}$ & $\begin{array}{l}\text { fluid-rock } \\
\text { interaction }\end{array}$ \\
\hline
\end{tabular}

1) Klinger et al. 2000; 2) Meghraoui et al. 2003; 3) Gomez et al. 2003; 4) Amit et al. 2002 (for earthquakes of magnitude of 6-7); 5) Ben-Menahem 1991; 6) Begin et al. 2005; 7) Kagan et al. 2005 